Wacana Vol. 20 No. 1 (2019): 56-92

\title{
The Mboi collection of Atma Jaya Catholic University in Jakarta
}

\author{
EDWIN P. WIERINGA
}

\begin{abstract}
Since 2018 the private collection of Ben Mboi (1935-2015), who is best known as Governor of East Nusa Tenggara - NTT - from 1978 to 1988, has been part of the Library of Atma Jaya Catholic University in Jakarta, where it is publicly accessible under the name of Ben Mboi Research Library. The collection totals 22,890 items; the majority of the books are written in English, Indonesian, and Dutch. After briefly introducing the life and work of Ben Mboi, this article first discusses the phenomenon of private libraries in Indonesia, making it clear that Mboi's collection is highly unusual. The main part of the paper explores the question as to what is specifically "Mboian" about the library and what it tells us about his mindset. Mboi's library functioned as a collection for a working mind and the essay focuses on his books dealing with good governance, which increasingly occupied Mboi's mind after he entered the world of politics. Special attention is paid to reader's marks and annotations: Mboi read his books from a decidedly Indonesian perspective. This is particularly evident in the case of Dutch books written by Dutch academics on contemporary Dutch society, which Mboi studied intensively in order to reflect upon the situation in post-Suharto Indonesia. Mboi's own political thinking, which advocated elitism and organicist statecraft, conformed to mainstream ideological discourse in the New Order, but is still de rigueur in post-Suharto Indonesia, showing a remarkable overlap with colonial ideas about leadership in the period of Dutch high imperialism.
\end{abstract}

EDWIN P. WIERINGA is Professor of Indonesian Philology with special reference to Islamic cultures at the University of Cologne. He holds an MA and a PhD in Indonesian philology from Leiden University. He was Von Humboldt Fellow at the University of Münster in 1997-1998; Visiting Professor at Tokyo University of Foreign Studies (TUFS) in the winter term of 20152016; Brill Fellow with the Scaliger Institute at Leiden University Library in July 2016 and the first recipient of the Ben and Nafsiah Mboi Fellowship at the University Library of Atma Jaya in Jakarta in August-September 2018. His special interests are literary and religious practices in traditional and modern insular Southeast Asia. For a related article on the subject of book collecting and readers writing in books, see his 2018 article "Malay graffiti in a nineteenthcentury lithographed Qur'ān", Heritage of Nusantara; International Journal of Religious Literature and Heritage 7(1): 79-93. Edwin P. Wieringa may be reached at: ewiering@uni-koeln.de. 


\section{KEYWORDS}

Ben Mboi; Nafsiah Mboi; private library; book collection; NTT; knowledge production; Dutch language in Indonesia; marginalia; good governance; Pancasila discourse; reader-response criticism.

\section{INTRODUCTION $^{1}$}

The Ben and Nafsiah Mboi collection is an international research library donated by Dr Andi Nafsiah Walinono Mboi to the Catholic University Atma Jaya in Jakarta, which was officially established as a facility of the University on 15 August 2018. The material received by Atma Jaya at this time totals 22,890 items written in 21 languages, collected between 1955 and 2015 by Nafsiah Mboi's late husband Dr Aloysius Benedictus (“Ben”) Mboi (1935-2015). In due course Nafsiah Mboi, who was born in 1940 and who is an Indonesian physician and politician, will also add her own materials to the collection at Atma Jaya, hence the name "The Ben and Nafsiah Mboi collection". Nafsiah Mboi's papers will include materials from her domestic and international work, relating among other things to women's emancipation, communitybased rural activity (especially public health), children's rights, HIV and AIDS, and papers from her term as Minister of Health (2012-2014).

This essay will describe and discuss Ben Mboi's collection, now known under the name of Perpustakaan Riset Ben Mboi (Ben Mboi Research Library), which is located on the floor above the ground floor (that is, the second floor in Indonesian parlance) of the University Library of Atma Jaya on its main campus in Semanggi area, South Jakarta. Generally, private collections tend to disappear along with their owners, dispersed after the deaths of their onetime collectors. Ben Mboi's private library, which has now become available to the public, is fortunately still intact and very much represents the mind of its collector, reflecting the interests of a prominent member of the ruling elite who hailed from the Indonesian province of Nusa Tenggara Timur (NTT). ${ }^{2}$

Unlike most other members of Indonesia's oligarchy, who are commonly born in Jakarta or another major city on Java and are generally Muslim (Poczter and Pepinsky 2016), Ben Mboi was born on 22 May 1935 in the smallish town of Ruteng in Manggarai, West Flores, that is, on a small island away from the bustle of the capital, and belonged to the Catholic minority. Mboi's singular life and anomalous career are of particular interest, all the more so since NTT, as Karen Houston Smith (2011: 8) phrases it, is an area "about which much

1 I wish to thank Dr Svann Langguth (German Embassy, Jakarta) who first alerted me to the Mboi collection and put me in contact with Atma Jaya. At Atma Jaya, I am especially indebted to Dr Elisabeth Rukmini (Vice Rector), Dr Agustina Nurcahyanti (International Office), and Ms Santi Kusuma, SPd, MSc (Library) for facilitating my visit in August-September 2018. I would also like to thank Dr Nafsiah Mboi and Ms Karen Houston Smith who kindly agreed to be interviewed.

2 The province NTT or East Nusa Tenggara, which was officially created in 1958, consists of the islands in the Eastern portion of the Lesser Sunda Islands group, namely Sumba, Flores, Komodo, Rinca, the Solor Islands, the Alor Islands, Sawu, Roti, Semau, and the western half of Timor. 
less is known than Java and [sic] some other parts of Indonesia". As Smith (2011: 8) remarks further, most of Mboi's professional life as a doctor and later as Governor of NTT were "out of sight". Mboi's life-story constitutes a remarkable chapter in the larger story of Indonesia.

Until the beginning of the twentieth century, West Flores or Manggarai was still under the rule of the Muslim Sultan of Bima, but in 1907 the Dutch took possession of the region, after which Catholic missionaries succeeded quite quickly in converting almost $90 \%$ of the local population to Christianity (Steenbrink 2013; Willemsen 2015: 79). The provision of education was entrusted to the Catholic missionaries, resulting in the creation of an intellectual elite. Mboi (2011: 22) recounts in his autobiography that his father was born in 1907 as the son of a raja, coincidentally in the same year as the Dutch "pacification of Flores", and hence enjoyed a Dutch education, subsequently becoming a mantri hygiene (hygiene officer), that is, a rural health worker in the colonial public health service, while in the evening acting as a religious teacher (guru agama) who gave instructions in the Catholic catechism. His mother too had an impressive aristocratic genealogy (Mboi 2011: 32).

However, in the rhetoric of his public self-representation, Mboi (2011) invariably stresses the rather humble economic circumstances of his youth and early adulthood, time and again referring to himself as "the son of a toilet manager" (anak mantri kakus; kakus is derived from Dutch kakhuis, literally 'shit house'). For example, recalling the moment when he officially became a doctor in 1961, he mentions that he had come a long way as the son of a toilet manager, thereby suggesting the story of a boy risen from the slums (Mboi 2011: 130). Another example, among many others, of his insistence on his supposedly humble background is to be found in connection with his marriage to Nafsiah in 1964: "I was merely the son of a toilet manager. Aristocratic merely in name, without owning anything" (Mboi 2011: 196).

Mboi assiduously cultivated his populist credentials as being "the son of a toilet manager" in his rhetoric (see Mboi 2009b: 17), stressing that his father, despite his noble background, was rock-bottom dirt poor. However, without wishing to call into question the financial difficulties which Ben Mboi may have endured in the early phases of his life, it should be noted that the term "toilet manager", which evokes a rather humiliating and degrading job as toilet cleaner, does not denote that his family belonged to the lowest socioeconomic class. On the contrary, "toilet manager" was in fact a humorously disparaging term applied to the overseers of the colonial hygiene project, who always belonged to the local elite, being highly educated and influential persons and figures of authority (Stein 2009: 550). Portraying himself as the son of a toilet manager obscured another and quite different narrative of Mboi's life-story, namely that of Ben Mboi as the son of aristocratic yet impoverished parents who due to his own meritocratic efforts became a member of a new elite in postcolonial Indonesia and married a woman from a rich, aristocratic family in South Sulawesi, a woman whose father was the Raja of Sengkang (Mboi 2011: 196). 
Financial hardships notwithstanding, Mboi received a Dutch education from Catholic priests, at first in Flores, thereafter (in his high school years) in Kupang, Timor (1949-1952) and later in Malang, East Java (1952-1955) (Mboi 2011). From 1955-1961 he studied at the Faculty of Medicine of the Universitas Indonesia in Jakarta, subsequently working as a physician. However, Mboi is remembered best for his distinguished career in the Indonesian army and in government. He achieved the rank of Brigadier General and was Governor of NTT for two successive periods (1978-1988). He acquired a reputation as a political go-getter, and in 1986 he and his wife Nafsiah jointly received the Ramon Magsaysay Award for Government Service. For many years he was a member of the People's Consultative Assembly (Majelis Permusyawaratan Rakyat, MPR).

Mboi belonged to what Bill Watson (2006: 165) has dubbed the "third and arguably last generation of Indonesian nationalists", that is, those born in the twenties and early thirties of the twentieth century. ${ }^{3}$ Too young to play a role in the Indonesian War of Independence (1945-1949), he was a fierce nationalist who was able to prove his patriotism in the TRIKORA military operation of 1962, which resulted in Indonesia's takeover of Western New Guinea. ${ }^{4}$ Henceforth, entering the militarily affiliated political elite, Mboi made his career under Suharto's military-backed New Order.

Having become acquainted during the Western New Guinea campaign with his co-religionist Benny Moerdani (1932-2004), Mboi recounts in his autobiography how his former comrade-in-arms, who had meanwhile become a powerful general holding key positions in intelligence affairs, approached him some time in 1977 with the following direct question: "Doc, you want to become Governor of NTT? Tomorrow there will be a meeting at the Department of Defence and Security!" (Mboi 2011: 295). It was his "old friend" (kawan lama), General Ali Murtopo (1924-1984), known to historians as one of the most prominent architects of the New Order political landscape and the chief strategist behind Indonesia's policy on East Timor, who ordered Mboi to go to Kupang in order to secure stability in West Timor at a troubled time when neighbouring East Timor constituted a "problem" (masalah) for the New Order regime in the aftermath of the Portuguese decolonization (Mboi 2011: 295).

According to Mboi's memoirs, on the occasion of his official resignation as Governor in 1988 President Suharto asked him: "Ben Mboi, which post would you like to have?" (Mboi 2011: 459). Still according to his own account, Mboi (2011: 459) answered that he wanted "to go to school" in order to deepen his knowledge of governance, explaining that he wished to couple his practical

3 In Watson's categorization, those born before 1890 are considered as the first generation of nationalists, such as Tjokroaminoto or H. Agus Salim; the second generation were those born between 1895-1910, most famously Soekarno, Hatta, and Sjahrir. However, the third generation, which was born around the twenties and thirties, "never produced the same inspirational heroes of their two generations of predecessors" (Watson 2006: 91 notes 11, 92).

4 TRIKORA stands for Tri Komando Rakyat or Threefold Command of the People, announced in December 1961 by President Soekarno and which led to military operations in the next year. 
experience as a governor with the scholarly knowledge he would be able to gain at the University of Leiden in order to know how to achieve progress for Indonesia. The choice of the Netherlands was because the Dutch had been the "founders of the administration of modern Indonesia in the beginning" (Mboi 2011: 460). President Suharto granted his wish, but also urged him to subsequently attend Harvard University in order to comprehend how such a big country as the US was able to guarantee the welfare of its people (Mboi 2011: 460).

A book by Duverger (1979), The study of politics, which was acquired by Mboi in Jakarta in 1980 and is full of his usual reader's marks, serves to testify that Mboi's interest in political science and theories of statecraft was already evident when he was wielding practical power himself as a governor. However, it was only in his post-gubernatorial years that he was able to devote himself more or less full-time to studying "government and politics in action" as well as "democracy in action" (Mboi 2011: 492; English terms in the original). He spent some time studying in Europe and the US, but after returning to Indonesia in the early 1990s he continued to write and teach on these subjects and delivered speeches on them, while his expert advice on political matters such as decentralization policies was sought by people in high places. Judging from his own description of his teaching experiences in Indonesia (Mboi 2011: 492-495), reality apparently did not match up to his high ambitions, which made him stop offering college courses in 2000 (Mboi 2011: 493). However, this did not stop him from attempting to establish an Indonesian "Center for Studies of Government and Governance": a six-page plan for such an institute is to be found among the papers in his collection (dated 7 November 2002; not yet catalogued; no call number yet). Such an institution had already occupied his mind ever since he had left active service (see Mboi 2011: 489 for earlier plans), but it never materialized.

Apart from introducing Mboi's extraordinary collection to a wider academic public, this paper highlights the personal character of his private library, paying special attention to the books which he read and used intensively, as evidenced by his marginal comments and markings, mostly in the form of the highlighting of passages and lines and arrows in the margins. The paper is organized as follows: firstly, I will offer a brief glimpse of the phenomenon of private libraries in Indonesia, which still very much constitutes uncharted territory. In order to answer the question of what is especially "Mboian" about his library and what it tells us about his mind, I will then provide a general overview of Mboi's enormous collection, discussing its main subsections and most remarkable features. The next step will be an examination of the section of Mboi's private library that evidently occupied him most after he had entered the world of politics, namely books dealing with good governance. The reader's marks by Mboi have their own story to tell. The focus will be on the books in Dutch which Mboi read in the final years of his life in the post-Suharto era. Although these books as a rule discuss developments in contemporary Dutch society, for Mboi this foreign 
literature functioned as a prism or a point of reference by which to evaluate the situation in his own country. In the twenty-first century, Ben Mboi was one of the rare members of the Indonesian elite who was still Dutch-educated and had command of the Dutch language, even writing his comments in Dutch in Dutch-language books. However, as the final section of this essay argues, Mboi's political thinking, involving as it does such concepts as elitism and a commitment to a religiously oriented integralist ideology, shows him to be a typical representative of the postcolonial Indonesian ruling elite with its concomitant New Order rhetoric and a mindset which have a demonstrably Dutch colonial pedigree.

\section{PRIVATE LIBRARIES IN INDONESIA}

Although there are of course other book collections in Indonesia belonging to private individuals, a library on a scale of tens of thousands of books and documents is huge by any standards and is obviously beyond the financial ability of most collectors, not to mention the very practical problem of storage room. In order to put into perspective how unusual Ben Mboi's collection is, we should take into consideration that Indonesia is not a country of readers. The figures speak for themselves: as the German journalist Monika Griebeler (2015) observed in 2015, when Indonesia was Guest of Honour at the Frankfurt Book Fair, approximately 1,400 Indonesian publishing houses brought out an average of 24,000 titles per year, whereas Germany, while having significantly fewer inhabitants, not only has more publishers but also has an annual output of twelve times as many books. In terms of interest in reading, a 2016 report from Central Connecticut State University in the US showed that with regard to the amount that people read, Indonesia ranks next to last, just above Botswana, in a list of 61 countries for which an evaluation is possible (see, for example, news reports by Gunawan S. 2016; Rempah 2017).

Not much is known about book collectors and private libraries in Indonesia. Academic interest in this topic has hitherto also been very scarce, with the notable exception of privately owned manuscripts, which have received an increasing amount of international attention in the last decades, giving rise to many projects involving the identification, cataloguing, microfilming, and nowadays digitization of private manuscript collections from all over Indonesia (see Van der Meij 2017: 138-147). Generally funded by non-Indonesian institutions, these projects, in which team members are paid rather well by Indonesian standards, enjoy great popularity among Indonesian researchers, but so far the number of scholarly studies of the collections themselves and their contents is disproportionally small when compared to the amount of material which is now being made available to the public. ${ }^{5}$

5 For example, see Gallop (2014) for a discussion of Indonesian projects of the Endangered Archives Programme (EAP), inter alia concerning private collections in Aceh. Recently, the British Library and SOAS set up a doctoral programme aiming to investigate these digitized collections, which is still a rare thing, see Gallop 2018. This is not the place to list all the other programmes, but I would like to point out that there is still much to discover; as was evidenced 
Tim Behrend (1988) has given a brief overview of quite sizeable collections of Javanese handwritten books owned by some Javanese collectors, particularly those belonging to the traditional ruling elite (priyayi), while Ben Arps (1999) has discussed at some length the catalogue raisonné of the private collection of a Javanese gentleman in Surakarta compiled in 1948-1949, which contained not only manuscripts but also printed books, pamphlets, and magazines, not only in Javanese but also in Dutch and Indonesian.

However, academic literature that specifically discusses Indonesian private libraries of printed books seems to be almost non-existent. In the field of modern Indonesian literature one immediately thinks of the unrivalled Pusat Dokumentasi Sastra (PDS) H.B. Jassin (H.B. Jassin Literary Documentation Centre) in Jakarta, which was originally the private collection of the most influential critic or "pope" of modern Indonesian literature, Hans Bague Jassin (1917-2000). It has a total of 16,316 titles of fiction books and 11,990 titles of non-fiction books, but also 630 theses and dissertations on Indonesian literature and thousands of clippings about authors and their literary work plus lots of additional material (see Subhan 2012: 3). ${ }^{6}$ After many years of suffering from chronic financial problems and even facing possible closure, the H.B. Jassin Literary Documentation Centre was at long last saved in 2018 by being turned into an official Integrated Service Unit (Unit Pelayanan Terpadu) under the auspices of the Jakarta District Government.

Whereas Jassin's collection very much documents the "official" side of modern Indonesian literature, the importance of private collections for our view of Indonesian history is further underscored by the example of Myra Sidharta who has acted as a custodian of that Sino-Indonesian heritage which is generally disregarded in official discourse. Myra Sidharta (born Auw Jong Tjhoen Moy), born in Belitung in 1927, is a psychologist who has earned a great reputation as an expert on Sino-Malay literature. ${ }^{7}$ Her interest in this subject first started when a Dutch Catholic priest with whom she co-wrote articles on psychology encouraged her to study Sino-Indonesian women, which put her on the path of reading pre-war Sino-Malay novels in order to gain insights into "the making of the Indonesian Chinese woman" (also the title of one her many essays; Dawis 2012: 974). Her collection of the Sino-Malay literary heritage, which she has also made publicly available, is unique worldwide. As Tom Hoogervorst notes, "Leiden's online Sino-Malay collection would have been substantially less impressive if not for [sic] the hundreds of microfilms supplied

once again in August 2018 when the newly established DREAMSEA (Digital Repository of Endangered and Affected Manuscripts in Southeast Asia) project digitized sixty manuscript bundles from four owners in South Sumatra. See https:/ / dreamsea.blogs.uni-hamburg.de/ preserving-okis-manuscripts-safeguarding-the-ancestors-mandate/ (accessed on 23-8-2018).

6 See Subhan (2012) for a succinct description of the PDS H.B. Jassin and his discussion of the social movement \#Koinsastra which campaigned for the preservation of this institution in 2012.

7 See Sidharta (2011) for a personal account of her collecting activites. Incidentally, there is also a connection to Atma Jaya here: Myra Sidharta was married to Priguna Sidharta (Sie Pek Giok) (1924-2003), neurologist and professor at Atma Jaya, who donated his collection of medical books to the University. 
by Myra in the 1980s". ${ }^{8}$ This collection not only serves as a reminder that the history of modern Indonesian writing is far richer than officially admitted, but also shows how important it is to recognize that the texts of those who have meaningfully contributed to that history are valuable cultural artefacts.

Another well-known bibliophile is Mohammad Hatta (1902-1980), Indonesia's first vice-president, whose love of books is legendary. Even when he was imprisoned by the Dutch, he did not want to be separated from his books, which were his "first wife" (Kurniawan 2015). As he wrote in 1934 about his upcoming time in jail: "Books are my daily companions and certainly this is a peaceful place to study ... As long as I have books, I can exist anywhere..." (cited and translated by Rose 2010: 130). On the occasion of his marriage ceremony in 1945, the gift to his bride Rahmi was not money, as is usual, but a book that he had recently written himself on ancient Greek thoughts on democracy. According to Hatta's biographer Mavis Rose (2010: 213), Rahmi accepted it "knowing that books were Hatta's most treasured possessions".

A lover of books, Hatta took care that his collection remained in pristine condition, never dog-earing pages or making any marks (Kurniawan 2015). A doctorandus in economics from the Rotterdam School of Commerce and thrifty by nature, his carefulness could perhaps be interpreted in economic terms, as pre-owner marks, stains and damage invariably decrease a book's market value. A more ironic interpretation would be that Hatta's concern with cleanliness reflects the characteristically modern ideologies of order, hygiene, bodily self-control, decency and civilization that the colonial authorities propagated. ${ }^{9}$

The high walls of his house on Jalan Diponegoro 57 in Central Jakarta were invisible behind shelves filled with thousands of books mainly dealing with philosophy, politics and economics, not to mention magazines, journals, and encyclopaedias. ${ }^{10}$ After Hatta's death in 1980, his private collection turned into something of a museum, but the family lacked funds for the proper preservation of the library and could not afford to catalogue the books. ${ }^{11}$ This collection, estimated to consist of about 20,000 items, has meanwhile become a mausoleum which is costing Hatta's family a fortune: a few years ago it was reported that the monthly electricity bill alone was a big burden, which however it was essential to bear in order to provide the permanent air conditioning needed to keep the collection free of moisture (ahy/mok 2011).

This danger of a collection turning into a mausoleum was also one of the main reasons for Nafsiah Mboi to select Atma Jaya Catholic University as the ideal home for her late husband's library. Ben Mboi's long-term vision was to have his collection well preserved and well utilized as an international

\footnotetext{
8 See http://www.kitlv.nl/blog-books-written-everyone-protected/ (accessed on 11-09-2018).

9 On perceptions of cleanliness in colonial Indonesia, see Van Dijk and Taylor (2011).

10 See Anonymous (2010) for an impression of Hatta's collection, also mentioning several book titles that interested Hatta.

11 See Anonymous (2010), which cites Hatta's youngest daughter Halida as saying that a librarian wanted to be paid IDR 10,000 per book title, which would in the end have added up to an enormous sum of money.
} 
research library. Already in the mid-1990s he toyed with the idea of opening his collection to the general public in Kupang, and there are a few examples of books from this period that have been prepared for the use of the precomputer Browne issue system for the lending out of library books (Figure 1). However, setting up a public library in Kupang proved to be an impossibility, in the absence of all requisite facilities; nor did the local population show any real interest (Nafsiah Mboi, Jakarta, 13 August 2018; Santi Kusuma, Jakarta, 26 September 2018).

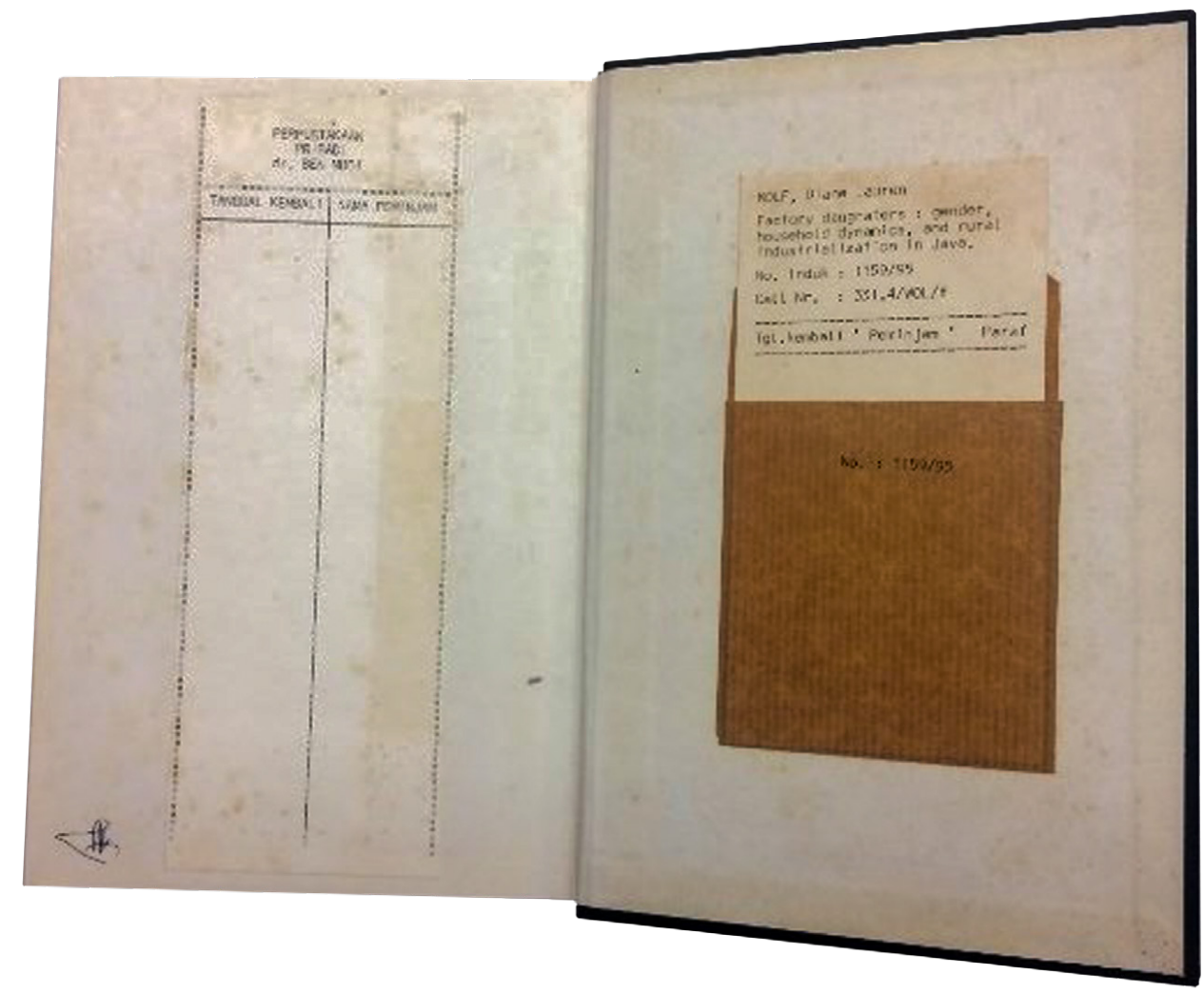

Figure 1. Example of a book in Mboi's collection prepared for the use of the precomputer Browne issue system for the lending out of library books. The signature at the bottom of the end flyleaf is that of one of the students belonging to the cataloguing team, signifying that the job has been done. (Perpustakaan Riset Ben Mboi Unika Atma Jaya, 331.4095982 WOL f).

Among the still living Indonesian bibliophiles with impressive collections is Azyumardi Azra (born in Padang Pariaman in 1955), who is a liberal Muslim thinker and prominent public intellectual. He has so many books that he has lost count of the exact number but perhaps the total may be somewhere around 15,000. Two-thirds are in English, the rest in Arabic and Indonesian. The majority of his books are on regional studies relating to the Middle East and Southeast Asia, which are his professional fields as a scholar. This is very much a professorial working library which is still located in the collector's own house, although a quarter of it is at his office at the Islamic State University Syarif Hidayatullah in Ciputat, Jakarta. Perhaps in the future 
his entire collection will be made available to this university. ${ }^{12}$ The case is different again with Fadli Zon, born in Jakarta in 1971, who is perhaps best known for his role as a politician of the Great Indonesia Movement Party (Gerakan Indonesia Raya, Gerindra) and as a current deputy speaker of the People's Representative Council. However, he is also an avid collector of books and antiquities related to Indonesian history, and has established his own library which is open to the public. This collection also includes Malay newspapers from the nineteenth century and more than a hundred Javanese manuscripts. ${ }^{13}$

Only very rarely has an Indonesian bibliophile written about his passion. Polycarpus Swantoro's 2002 Dari buku ke buku (From book to book) is on reading rather than collecting books. His musings on the books in his possession could perhaps best be described with the German term Lesefrüchte or "fruits of reading", being a collection of notes and observations in the form of short reviews of 200-odd books dealing with Indonesian history. When he wrote these at the age of seventy, Swantoro wished to transfer a part of his impressive library to a special museum in the place of his birth, Yogyakarta, hoping that his book collection might benefit the general public. ${ }^{14} \mathrm{His}$ collection of reviews was intended to arouse interest in Indonesian history among his grandchildren and their generation (Swantoro 2002). Intriguingly, Swantoro shares a Catholic background with Ben Mboi, having pursued a career as a journalist and editor at Catholic magazines such as Basis, Praba, and Rohani, and the national newspaper Kompas. A graduate of Jesuit seminaries, he first came into contact with world literature, including the Latin classics, under the guidance of Catholic priests. ${ }^{15}$ Mboi's interest in books, on the other hand, seems to have been more practically oriented, directly connected with his professional needs, initially as a doctor and later as an executive officer and politician. Mboi's library consists mainly of works he needed for his work.

\section{A COLLECTION FOR A WORKING MIND}

Writing about packing up his deceased father-in-law's collection of about four thousand books, the book critic and staff writer at The New Yorker James Wood (2011) states that "in any private library the totality of books is meaningful, while each individual volume is relatively meaningless". Wood goes on to say that the individual book is mostly not very special as it is owned by several thousand or even several hundred thousand people, which makes

12 See Azra's personal account of his book collection which is dated 6 April 2010 and posted at https://www.facebook.com/shofwankarim/posts/membaca-dan-menulis-sebuah-personalaccountapril-6-2010-at-1101amsumber-st-sular/918267514910729/(accessed on 11-09-2018).

13 The library has its own website, http://www.fadlizonlibrary.com/ and also its own Wikipedia entry, https://id.wikipedia.org/wiki/Fadli_Zon_Library\#Koleksi_Buku (accessed on 11-09-2018).

14 A short biography of Swantoro, who was born on 26 January 1932 in Wates, Kulon Progo, Yogyakarta can be found on http://www.penerbitkpg.id/book_author/p-swantoro/ (accessed on 20-8-2018).

15 See http:/ / www.penerbitkpg.id/book_author/p-swantoro/ (accessed on 20-8-2018). 
him wonder whether "our libraries perhaps say nothing particular about us at all" (Wood 2011). "If I were led into Edmund Wilson's library in Talcottville", Wood (2011) asks, "would I know that it was Edmund Wilson's library, and not Alfred Kazin's or F.W. Dupee's?" Or rephrasing the question with regard to Pushkin's library with about a thousand non-Russian books: "But what is especially Pushkinian about the library? What does it tell us about his mind?" (Wood 2011).

If we apply Wood's queries to Mboi's collection, is there anything "Mboian" about it? The large quantity of Indonesian books immediately points to someone with an Indonesian background (or an Indonesianist, for that matter), whereas the existence of books in many other languages betrays a well-educated person. Based upon an inventory of Ben Mboi's collection in Kupang and Jakarta made in March-April 2016, the vast majority are written in English (9,009 items), Indonesian (6,117 items), and Dutch (5,219 items). These three languages clearly opened up Mboi's main avenues of thinking: Indonesian is the official national language of Indonesia and preferred for publications, whereas Dutch was the language that well-educated Indonesians had learnt at school; after independence, English took over the role of Dutch as the prestige language.

Although the number of English publications would seem to reflect this general historical development, it should be noted that right up until the end of his life Mboi continued to buy and read the newest books in Dutch, which for him remained a gateway to international thinking. For example, it must have been his general interest in politics that induced him to acquire Gerrits (2006), which he bought from the Dutch Selexyz bookshop chain, but which is without his usual markings. The interesting point to observe here is that the subject the Dutch historian Gerrits (2006) deals with, is by no means some Dutch speciality; in fact, the bibliography of Gerrits (2006: 177-189) is almost completely Anglophone. His book discusses a controversial topic in Western foreign policy, namely the international promotion of democracy, addressing the hotly debated issue as to whether Western nations have the right, and whether it is permissible for them, to interfere in the affairs of other states on account of Western ideas of democracy.

Furthermore, a substantial number of books in Mboi's collection are in German (1,090 items) or French (1,028 items), of which Mboi had a good reading knowledge. Rather remarkable, at least in an Indonesian context, are the 278 books in Portuguese, which must have interested Mboi for documentary reasons due to the history of Portuguese colonialism in Indonesia, most notably in NTT and East Timor. Other languages such as Spanish (30 items), Japanese (5 items) or Russian ( 4 items) are only represented in small numbers. Contrary to what might perhaps be expected of a man who was so proud of his provincial descent, the collection has very few books in regional Indonesian languages: Sumba (18 items), Javanese (13 items), and Manggarai (13 items), and only one item each in Minangkabau and Sabunese.

Holding pride of place in the Mboi collection, and an item that was on 
display in the exhibition on the occasion of the opening of the library, is an oversized book consisting of a series of large maps documenting successive Portuguese voyages of exploration in the time of their first travels worldwide, as far as East and Southeast Asia, including splendid coloured charts of the Eastern Archipelago from the 1568 atlas by Fernão Vaz Dourado (plate XV in Cortesão and Teixeira da Mota 1960) and of Aceh on the northernmost tip of Sumatra (plate XVI in Cortesão and Teixeira da Mota 1960). In fact, this is a collection of facsimiles of early Portuguese nautical charts, published in 1960 as Tabularum Geographicarum Lusitanorum Specimen (Cortesão and Teixeira da Mota 1960). The maps are dated between 1519 and 1643. The website Worldcat. org lists only 25 libraries in the world which are in possession of this work. ${ }^{16}$

Generally speaking, the Portuguese books in Mboi's collection may perhaps prove to be among the most valuable textual treasures in Indonesia, as Lusitanian studies are still non-existent at Indonesian universities (apart from some elementary language courses) and hence Portuguese literature is rarely represented in Indonesian public libraries. For example, Indonesian researchers would be hard pressed to find such a Portuguese book as Leitão (1948) on the Portuguese in Solor and Timor between 1515 and 1702. A nice example of Portuguese colonial literature, the copy of which in Mboi's collection again seems to be the only one in Indonesia, is Teófilo Duarte's 1930 Timor (Ante-câmara do inferno?!) (Timor: Antechambere of Hell?!). ${ }^{17}$ The author was Governor of Portuguese Timor from 1926 to 1928 and the front cover of his book (Figure 2) employs the colonial trope of headhunting as an expression of indigenous savagery during the colonial "pacification" wars (see Roque 2010: 27-28).

The overwhelming majority of the items in Mboi's collection date from the twentieth century, a staggering 19,139 items in all, but there are a few older publications. The oldest dates from 1677, and was acquired by Mboi from a Dutch antiquarian bookseller; it is a rather rare copy of Gerret Vermeulen's late seventeenth-century account of his voyage to Southeast Asia (Vermeulen 1677). This is a primary source written by a soldier of the Dutch East India Company who had not only taken part in the final stages of the Makassar War of 1666-1669, but also described Bali, Timor, and the Banda Islands (see Lach and Van Kley 1993: 1359, 1424, 1447-1448, 1461). The early seventeenthcentury three-volume Histoire de la conquête des Isles Moluques par les Espagnols, par les Portugais, et par les Hollandois by Bartolomé Leonardo de Argensola and Lupercio Leonardo de Argensola (call number 741.50952 ARG h), published in Amsterdam by Jacques Desbordes in 1706, probably cost him dearly as well, but it has nowadays become accessible to all due to free global internet access. ${ }^{18}$

16 Listed in: http://www.worldcat.org/title/tabularum-geographicarum-lusitanorumspecimen/oclc/664521 (accessed on 31-08-2018).

17 Worldcat.org lists 31 libraries worldwide which have this book, but none in Indonesia, see http:// www.worldcat.org/title/timor-ante-camara-do-inferno/oclc/651427979 (accessed on 31-08-2018).

18 For example, SOAS library provides access through https://digital.soas.ac.uk/ AA00000859/00003/allvolumes (accessed on 03-09-2018). 


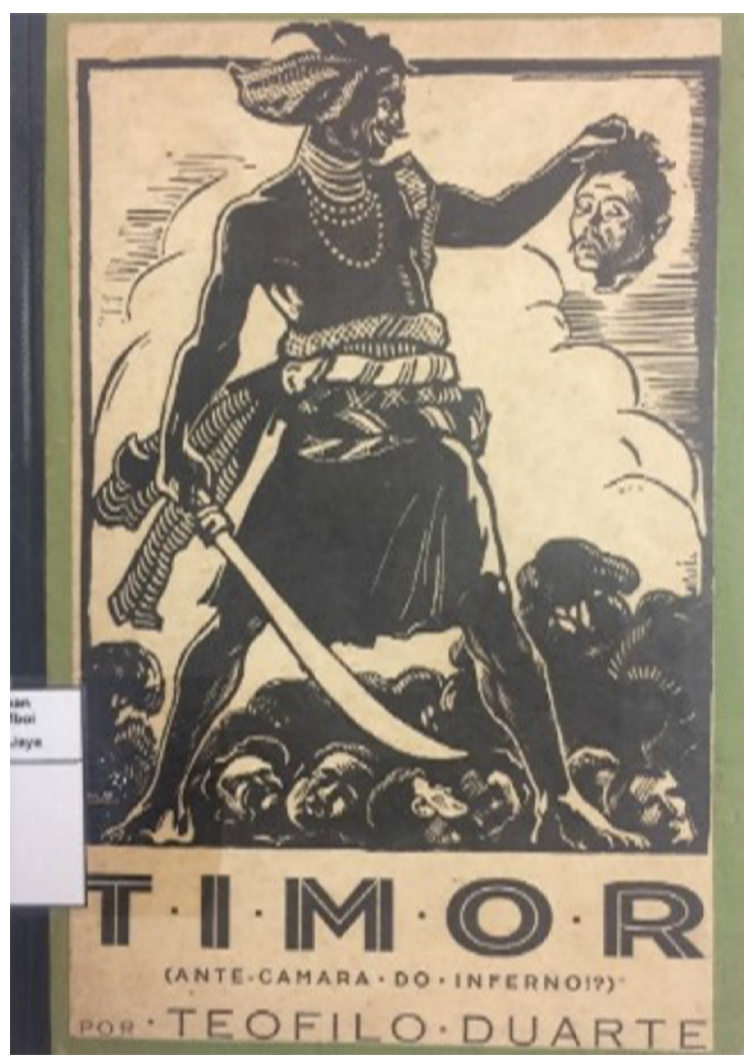

Figure 2. Front cover of Teófilo Duarte's 1930 book on Portuguese Timor with a macabre illustration of indigenous headhunting. (Perpustakaan Riset Ben Mboi Unika Atma Jaya, 959.86 DUA t).

As much as the man, Mboi's collection also reflects his time, namely the pre-digital era. Mboi must have been proud of his large collection of encyclopaedias. Entering the Mboi reading room of the Atma Jaya University Library, the visitor will immediately notice the shelves on the left-hand side containing the 30-volume Encyclopedia Americana (even twice, both the 1978 and 1986 editions), the 24-volume Encyclopaedia Britannica of 1967, the 20-volume standard Dutch encyclopaedia Grote Winkler Prins (third edition, 1975), the first edition of the 25-volume pre-war De Katholieke Encyclopaedie (1933-39; however, several volumes are missing) and the 7-volume Ensiklopedi Indonesia (1980-86).

The shelves full of encyclopaedias as authoritative reference books still printed on paper are silent reminders of a time only just recently ended. It was for example only in 2012 that Encyclopedia Britannica, Inc, announced that the 32 volumes of the 2010 edition would be the last, while future editions would be exclusively online. The editors of the Encyclopedia Americana may have claimed to have produced "an encyclopedia that is reliable, readable, and relevant to today's needs" (Cayne et al. 1986: iv); but that was in 1986, and the other encyclopaedias of Mboi's collection are even more dated. For a generation of digital natives that is used to an online knowledge market dominated by Google and Wikipedia, the gilt-edged tomes must create a 
feeling of being museum pieces.

In the digital age, a growing number of older publications are also becoming freely available online. The annual reports to the Dutch Parliament on the Dutch colonies known as Koloniaal Verslag (Colonial Report), which are to be found in Mboi's collection (call number R 325.3492 KOL), bound in hefty tomes, can nowadays also be consulted on the Dutch parliamentary website https://www.statengeneraaldigitaal.nl/. ${ }^{19}$ The flagship journal of the Dutch research institute on Indonesia, KITLV, namely the Bijdragen tot de Taal-, Land-en Volkenkunde, of which the Mboi collection has dozens of issues (call numbers R 301.0959 BIJ and R 301.205 BIJ) can also be freely consulted online. ${ }^{20}$ However, for some time to come it will still be the case that not all books are available online, and older books will only be available in paper form at a limited number of libraries, including some that remain among the most important resources for research in the humanities.

Another Dutch primary source which should be mentioned here on account of its importance for Indonesian history consists of twelve bundles of documents from the Round Table Conference of 1949 in The Hague, which Mboi acquired from a Dutch antiquarian bookseller. ${ }^{21}$ Although a large number of the official documents surrounding the Dutch-Indonesian conflict of 1945-1949 have been published in the meantime, the open access period of the Round Table Conference archive began only on 10 September 2015 and the documents in Mboi's collection do not (yet) seem to be available in digitized form. ${ }^{22}$

The same goes for the so-called grey literature from Mboi's active period in politics as Governor of NTT; that is to say, government reports, policy statements and papers on specific issues that are generally unpublished..$^{23}$ This kind of literature is by definition "non-conventional, fugitive, and sometimes ephemeral" and hence difficult to access. ${ }^{24}$ The Mboi collection is particularly rich in grey literature concerning NTT, and this archival material may be difficult if not practically impossible to access elsewhere: for example, a 1977 proposal for a Komodo National Park (R 639 PRO), a statement of the Minister

19 These government reports on the state of the Dutch colonies appeared in 1852-1939, but the Mboi collection includes only a certain number of them.

20 See https://brill.com/view/journals/bki/bki-overview.xml or https://www.jstor.org/ journal/ bijdtaallandvolk.

21 These documents have not yet been catalogued and do not yet have a call number (Santi Kusuma, 04-09-2018).

22 For an inventory of the Round Table Conference archive, see Kramer (1984) which is available online. The most comprehensive publication of official Dutch archival records on the Indonesian War of Independence 1945-1949 is the twenty-volume compilation edited by Van der Wal and later by Drooglever and Schouten, Officiële bescheiden betreffende de NederlandsIndonesische betrekkingen 1945-1950 published between 1971 and 1996, and now also available online.

23 Grey literature can be defined as "that which is produced on all levels of government, academics, business and industry in print and electronic formats, but which is not controlled by commercial publishers" (see http:/ / www.greylit.org/about; accessed on 21-11-2018).

${ }_{24}$ See http://www.greylit.org/about (accessed on 21-11-2018). 
of the Interior on agrarian matters given during a meeting in Jakarta in March 1980 (R 630 PEN), or several maps documenting forest management plans in NTT in 1987 (R 634 REN). Local publications on NTT matters, such as Skera and Lema (2013), are equally hard to find elsewhere and the Mboi collection is certainly unique in this respect as well.

The cataloguing of the Ben Mboi collection is presently under way. The catalogue is available and searchable online at https://lib.atmajaya.ac.id/ default.aspx?tabID $=52 \& j d l=\& l o c=14 \& j n s=1$. The books are classified using the Dewey Decimal Classification (DDC) system; in order to find the relevant code quickly, the cataloguers have made use of the OCLC website (www.oclc. org). Cataloguing the books has been prioritized, whereas the documents will be digitized in a subsequent phase. By 4 September 2018 a team of 23 students had already catalogued 9,800 titles (Santi Kusuma, 04-09-2018). However, the collection also contains a fair share of multiple copies of the same work and unfortunately this fact is not reflected in the call numbers. For example, Mboi had two identical copies of Beck (1997), which are both marked "Jakarta" but undated. Yet both copies have been given the same call number (303.4 BEC r), so it appears only once in the catalogue; but whereas one copy is full of coloured markings and marginal notes on pages 1-23, the other one only has a few underlinings and marginal arrows in red ink on pages 6-8. Intriguingly, exactly the same passages attracted Mboi's attention in both cases. However, there are also (for example) two copies of Luitnan (2012) on Kupang in the old days, which have also both been given the same call number (959.868. LUI k) and are both still in untouched condition. ${ }^{25}$ In view of Mboi's interest in all matters relating to NTT it is easy to understand that this book entered his collection, but there is no information on how and when he acquired it. In the case of the two copies of Vatikiotis (1993) (both with call number 959.803 VAT i), the duplicate was a gift (undated; inscribed "Dari Nell + anak2", that is "From Nell + children").

It should be noted that not all the books that entered Mboi's collection must necessarily have been of particular personal interest to him; which should make us wary of drawing firm conclusions about the mind of the collector merely by observing what is on the shelves. For example, a significant number of books in Mboi's collection, notably those concerning Dutch, German, and French belles-lettres and world literature, once belonged to an earlier private collection of another Indonesian bibliophile, namely Professor Soetan Mohamed Sjah, an Indonesian jurist known for his publications on legal terminology in the 1950s and 1960s (Massier 2008: 2), who had been Rector (1968-1976) of Universitas Nusa Cendana, the first state university in NTT, and a noted lover of books (Arge 2008: 296-297). ${ }^{26}$ Mboi himself, however, does

\footnotetext{
25 According to the catalogue, one of the two copies may be borrowed, but which one would that be?

26 My impression formed by randomly taking books from the shelves is that many if not most of the books in the Dutch, German, French and world literature section once belonged to Sjah's library. Some have the "Ex Libris S. M. Sjah" (for example 839.3145 MUL d and 839.3146 BRA g, which were both gifts from the Dutch ambassador to Sjah, dated 25-07-1972), while others
} 
not really seem to have been an enthusiastic reader of fiction, even though the belles-lettres subsection of his collection might suggest otherwise. ${ }^{27}$

Furthermore, friends and family regularly gave him books as gifts; and he was obviously also the recipient of such gifts in his position as Governor and an influential public person. For example, a compilation of anthropological essays on East Indonesia (Fox 1980) has a dedication by the editor "to Governor Ben Mboi, with good wishes and best regards", dated 3 August 1982, and is still in pristine condition (301.295986 FOX f). Yet the gifts may not always have matched Mboi's personal interests. ${ }^{28}$ For example, the Indonesian Linguistic Development Project (ILDEP) of Professor Wim Stokhof (born 1941) presented Mboi with several publications during his sojourn in Leiden, but these books are still untouched. ${ }^{29}$ Having been a civis academiae lugduno-batavae at this particular period, I happen to know that the multivolume Indonesian translation of documents containing official advice from Snouck Hurgronje to the colonial government (Gobée and Adriaanse 1990-95) once constituted a favourite promotional gift within the framework of another project of Stokhof's (who was "a talented large-scale research manager" (Kuitenbrouwer 2014: 262) at Leiden University in the 1980s and 1990s), namely the IndonesianNetherlands Cooperation in Islamic Studies (INIS). There is an incomplete set of Snouck Hurgronje's opinions and recommendations in Mboi's collection and a card (undated) from Professor Jacob Vredenbregt ("Representative for Asia" of Leiden University), still attached to the eighth volume, identifies it "as a gift" (sebagai hadiah). However, the mint condition of the volumes seems to indicate that Mboi never otherwise touched them. ${ }^{30}$ I mention this example, because without knowledge of the story of a book's provenance, misapprehensions may easily occur: for example, the (wrong) idea that Mboi may have been influenced by the Dutch Orientalist Snouck Hurgronje (18571936), who has a rather dubious reputation in Indonesia.

have his name on the flyleaf. A book by the Dutch novelist Hella Haase (915.9820437 HAA k) was also a gift to Professor Moh. Sjah, dated 18-10-1971 in Jakarta, but the signature is illegible. Unfortunately, the online catalogue does not mention such information.

27 As Dr Yohanes Eko Widodo (Atma Jaya, 26-09-2018) points out, the Mboi collection does not show any evidence that its collector was a "fan" of any particular fiction authors or literary genres.

28 Some of the books in Mboi's collection are even gifts to his wife, such as Kieboom (2005) which was presented to Dr Nafsiah Mboi in Antwerp in June 2009, wishing her success with her AIDS programme in Indonesia (Dutch note on flyleaf). Nevertheless, the highlighter markings on pp. 13-15 are definitively Ben Mboi's.

29 Browsing through the shelves, I noticed among others D'Haen (1990), Schulte Nordholt (1990), Wieringa (1990) from the Leiden Semaian series which were gifts "with the compliments of the Indonesian Linguistics Development Project (ILDEP)". Inserted in the copy of D'Haen (1990) are also two photos of the Mboi couple with many shopping bags. Incidentally, due to the classification system the books are separated: D'Haen (1990) is classified as 890 HER, Schulte Nordholt (1990) has call number 362 NOR o, whereas Wieringa (1990) is registered as 899.209 Wie c.

30 Incidentally, the set is incomplete, lacking volumes II and VII, but having volume IV twice. Volume VIII is the last volume, although in fact the set consisted of eleven volumes altogether (Gobée and Adriaanse 1990-95). The call number for all volumes is R 320.95 GOB. 
On the other hand, a booklet on the relationship between Jakarta and Papua, written by Neles Tebay (2009) and sent by this author to Mboi on 23 June 2009 from Jayapura must have been received most positively, as is indicated by several markings in orange highlighter (for example, underlining the statement in Tebay (2009: 1) that "the way of violence will not succeed in solving the Papua conflict"). Obviously it would go beyond the scope of this article; but an overview of the gifts would reveal the collector's network. ${ }^{31}$ This would involve the laborious work of thumbing through thousands of volumes: for example I discovered, inserted in Martin and Schumann (1996), a personal letter dated 11 March 2013 from an Indonesian expatriate in Berlin, reacting to Mboi's 2011 memoirs; the writer had sent the book to Mboi as a souvenir gift (call number $337 \mathrm{MAR}$ g). Such finds of personal letters are not unusual: in the Indonesian-Dutch dictionary by Moeimam and Steinhauer (2005; call number R 439.3139921 MOE k) there is an undated letter from the Indonesian (Catholic) doctor Koen Hay Oei, who worked as an internist in Oss, The Netherlands, to Ben and "Naf" Mboi, written on a medical prescription slip, asking about Ben Mboi's health and sending along some medicines that should have been enough to last him for some two months. ${ }^{32}$

It is difficult to ascertain when the great expansion of Mboi's collection really set in. As he had been active as a doctor in both civilian and military settings, it is obvious that his library would contain a notable section on medical matters; but it also includes various aspects of public health, health insurance and traditional medicine. Apparently, most of these medical books were acquired during his active days as physician. For example, a book on medical emergencies (Murphy et al. 1958) has the note "dr Ben Mboi 5/3-1962" and the stamp "MILIK dr. BEN MBOI" (that is 'owned by dr Ben Mboi'). A handbook on obstetrics (Greenhill 1955) was bought in Jakarta at Christmas 1958. Unfortunately, such dated copies are not the rule.

Military affairs were also among Mboi's favourite themes. His collection contains many books on military history, modern warfare, strategy, tactics, weapons and the like, but my impression is that these were acquired in bulk in his post-gubernatorial years and appealed to him due to his own military background. A considerable part of this subsection appears to have been bought in India; during one particular visit, Mboi is said to have sent home a shipping container full of books (Karen Houston Smith, Jakarta, 13 August 2018).

31 Unfortunately, the minimal catalogue descriptions do not contain information on inscriptions in the books. For example, in the case of Tebay (2009), it is not noted that the flyleaf contains a dated dedication by the author. In a network analysis, it would also be worthwhile to look at the contribution of the collector to tributes to others. For example, in Mboi's collection we find Triantoro (2005), but its importance to Mboi becomes more apparent when we learn that Mboi himself contributed an article to this volume in commemoration of General Benny Moerdani, whom he had known very well (Mboi 2005).

32 K.H. Oei passed away in 2015, see https://atmajaya.ac.id/Web/KontenFakultas. aspx?gid=berita-fakultas\&ou=kedokteran\&cid=TURUT-BERDUKA-CITA (accessed on 2809-2018). A brief memoir of him can be found in Oei and Kwee (2010: 179-187). 
According to family anecdotes, Mboi started collecting books seriously when he was a governor and felt the need to inform himself on all kinds of matters that he was confronted with daily. His impressive range of encyclopaedias and dictionaries would point to this urge (Nafsiah Mboi, Jakarta, 13 August 2018). ${ }^{33}$ In his own memoirs, a certain key moment is mentioned which sparked his interest in antiquarian books: during a study visit to Sweden, Denmark, and the Netherlands in 1984 he met a collector of old books on the Dutch East Indies, which inspired him to buy books from such Dutch antiquarian booksellers as Gé Nabrink and C.A. Valenbreder (both then in Amsterdam) and the Dutch book chain De Slegte (Mboi 2011: 473). ${ }^{34}$

However, I think that it was in his later, post-gubernatorial years that Mboi had the time and the funds to really expand his collection. Karen Houston Smith (Jakarta, 13 August 2018) recalled that when Mboi detected all kinds of second-hand bookshops on a visit to Harvard, Boston, US in 1990-1991, he just emptied the shelves. ${ }^{35}$ My impression is that in the period 1988-2015 Mboi acquired far more books than he could read, a phenomenon known in Japanese as tsundoku, which does not have a direct equivalent in English. About this habit of book hoarding, Wood (2011) writes that the acquisition of a book signals "not just the potential acquisition of knowledge but also something like the property rights to a piece of ground: the knowledge became a visitable place".

There is of course nobody who has read his or her entire library, and although the segment on governance and leadership was a veritable working library, the majority could perhaps be described as "an underemployed collection for a working mind" (Wood 2011). I hasten to add, however, that the term "underemployed" is perhaps not so felicitous, as it may easily evoke the idea that the books were simply amassed without being used at all, which is not the case. My use of Wood's expression should be understood in a matterof-fact way: when one possesses tens of thousands of books, the condition of their being underemployed is simply a given. In any case, Mboi is known to have mined his collection for citations in foreign languages which he used to spice his speeches, dazzling his enthusiastic audiences (Bibang 2015).

Incidentally, not all books in Mboi's collection are work-related: some books deal with his pastimes and relaxations, such as books on playing tennis

33 According to a stock list provided by the Mboi estate, there are 257 encyclopaedias and 157 dictionaries; the figure for encyclopaedias must refer to the total number of volumes and not sets.

34 For example, among the many documents and papers in the collection (not yet catalogued), I also happened to see a 1987 bill from C.A. Valenbreder in Amsterdam for several Dutch books on Timor, Flores etcetera.

35 In 1990-1991 he was a visiting scholar at Harvard Institute for International Development, while his wife Nafsiah was a research fellow at Harvard School of Public Health, see Mboi (2011: 488). One of the books which was bought then must be Fleishman, Liebman, and Moore (1981), which is inscribed "Ben Mboi Harvard '91" (172.2 PUB). It contains reader's marks only on pp. 1,3-8. Mboi has summarized some points in English on page 1, mixed with Dutch expressions: "even belangrijk" (just as important); "b.v" (for example) and "Beginselen van behoorlijk bestuur" (Principles of good governance). 
(Fraser 1975; Bohlens 1983) and bridge (Sheinwold 1968), and on wine (Johnson 1988) and gardening (Hay 1975). ${ }^{36}$ However, boundaries are not always so clear-cut: for example, a book on gardening by Seifert (1972), which was a gift from the Belgian missionary René Daem (1912-1994) who had worked on Flores since 1953, was most probably work-related. ${ }^{37}$ In the 1970s Daem was engaged in activities promoting small-scale local agriculture (see Edwards 2013: 77), and perhaps he considered this gardener's manual on working the soil without applying poisonous substances, written by Germany's leading specialist in organic gardening, to provide a worthwhile approach. Inserted in the book is a Dutch thank-you letter from Mboi, dated 13 July 1975 (631.875 SEI t); Mboi writes that he had studied the book with interest (although it does not contain any reader's marks), judging that "It is interesting, although here and there it still raises questions" (Het is interessant, ook al roept het hier en daar toch ook vragen op). However, Mboi's collection also includes the usual Agatha Christie books, a Sue Grafton murder mystery novel and some airport novels such as by Tom Clancy (1988; a 1991 Easter gift from a colleague; 813.54 CLA c) or by Jeffrey Archer (1998) and the first novel in the Harry Potter series by British fantasy author J.K. Rowling (2001), which was bought at the Dutch bookshop Van Ditmar.

In his memoirs, Mboi (2011: 475) writes that when he returned to Indonesia in July 1990 after his Dutch sabbatical, he brought with him "a warehouse of literature" (segudang literatur) on good governance, especially concerning decentralization and regional autonomy. Contrary to most other books, the section on governance is full of reader's marks, a token of intensive use. Here we have an engagement with books that left material traces behind.

\section{READER'S MARKS AND ANNOTATIONS}

It is somewhat ironic that some of Mboi's books, which are heavily marked in fluorescent highlighter and which contain his marginal and interlinear scribblings, now form part of a public library that strictly forbids the marking of books. However, as Jackson (2001: 167) points out, unmarked or "clean" lifetime library books or what she calls "career library books" - "that is, copies bought for the libraries in the first place, that have never had private owners and that would have been subject to prohibitions about marginalia" - cannot

\footnotetext{
36 It is a fact that only very few people are able to read Dutch in postcolonial Indonesia. The student cataloguers at Atma Jaya had no knowledge of Dutch and the many Dutch books in Mboi's collection must often have been beyond their comprehension. For example, as a native Dutchman, I could not help noticing that Nieuwenhuijsen (1985) is wrongly categorized as being concerned with plants (call number 632 NIE g), which must have been caused by the Dutch term proeftuin (experimental garden), but this is used metaphorically here ("testing ground") and the booklet is in fact about governance, dealing with the role of municipalities in the welfare state.

37 Daem has his own Wiki entry, https://nl.wikipedia.org/wiki/Ren\%C3\%A9_Leon_ Antoine_Daem (accessed on 12-09-2018). Mboi's collection also contains Moreels (1976), not only with the name "R. Daem" on the flyleaf, but also with his ex libris ownership stamp featuring the Latin words Disce Doce (Learn and Teach) and the place name Waerana, where Daem lived (call number 839.3131132 RUU v).
} 
tell us anything about readers' responses. As Leah Price (2008) elegantly phrases it, "Marginalia appeal to scholars' voyeurism, letting them peer over a past reader's shoulder".

Regrettably, however, I cannot do comprehensive justice to these marginalia. They are not only simply too numerous, but my selection also had to be done haphazardly in a hit or miss fashion, taking books from the shelves and looking for scribblings and underlinings. Unfortunately, the online catalogue does not provide information on the appearance of reader's marks. For example, entering the author's name "Kinneging" in the search engine will result in two references, namely Kinneging 2005 and Kinneging 1997 (Figure 3).

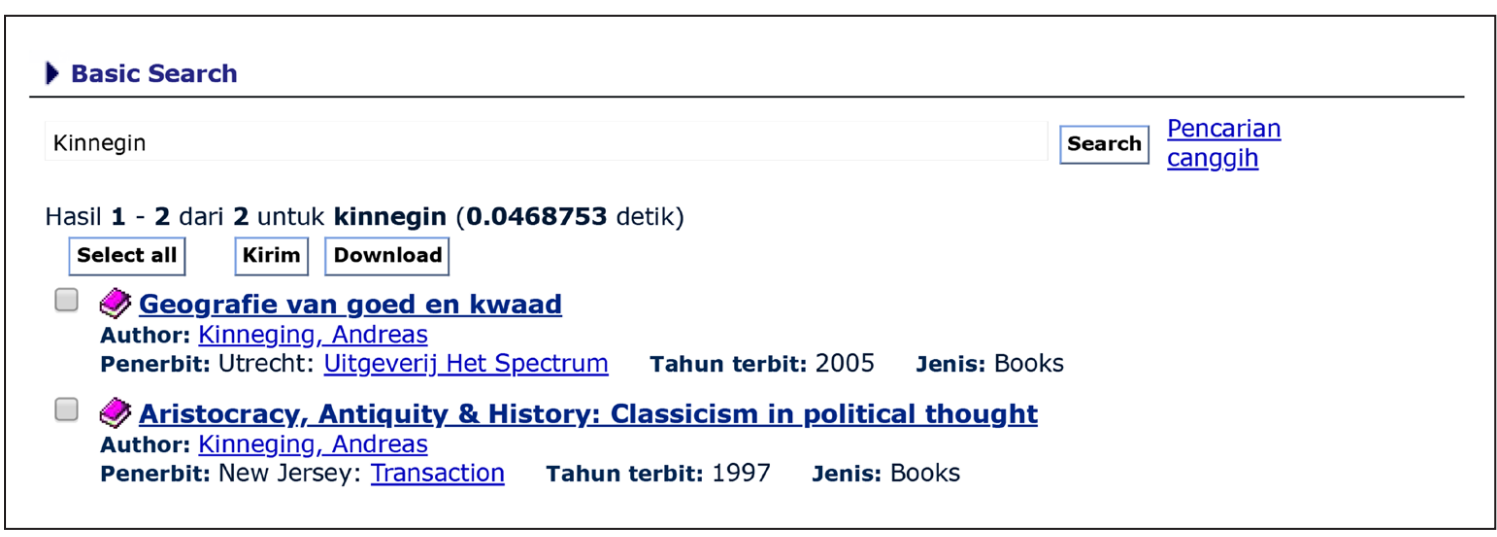

Figure 3. Catalogue information on books by Kinneging. Screenshot of https://lib. atmajaya.ac.id/default.aspx?tabID=53\&kt=Kinneging (detail), made on 21 August 2018.

Clicking the first result, namely Kinneging 2005, will provide more bibliographical information (Figure 4).

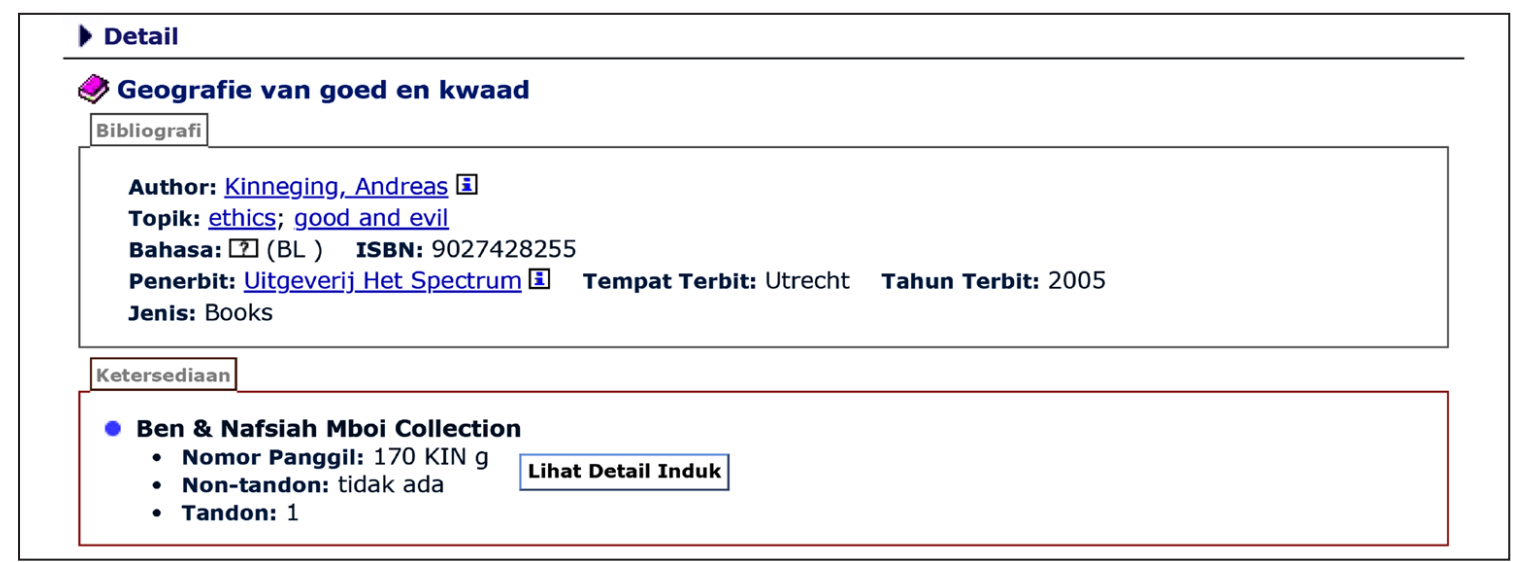

Figure 4. Catalogue information on Kinneging (2005). Screenshot of https://lib. atmajaya.ac.id $/$ default.aspx?tabID=61\&src=k\&id=212696 (detail), made on 21 August 2018.

However, clicking the box "Lihat Detail Induk" (see registration details) hardly provides much more information on the book, apart from the name of the publisher (Figure 5). 
- Detail Induk

Geografie van goed en kwaad (2005)

Bibliografi

- Pengarang: Kinneging, Andreas

- ISBN : 9027428255

- Bahasa: ? Dutch (Belanda)

- Penerbit: Uitgeverij Het Spectrum

- Tahun terbit: 2005

- Jenis: Books

Lokasi: Ben \& Nafsiah Mboi Collection

Filter berdasarkan Nomor Induk $\nabla$ :

Filter

\begin{tabular}{|r|l|l|c|c|c|c|c|}
\hline No. & Nomor Induk & Nomor Panggil & Tandon & Format & Thn. Cetak & Ket. Letak & Status \\
\hline 1 & 201814000149 & $170 \mathrm{KIN} \mathrm{g}$ & Yes & Printed (default) & & & Submitted \\
\hline
\end{tabular}

Back

Figure 5. Catalogue information on Kinneging (2005). Screenshot of https://lib. atmajaya.ac.id/default.aspx?tabID=470\&id=212696\&lok=14 (detail), made on 21 August 2018.

In fact, however, while Kinneging's book did originally appear in 2005, the copy in Mboi's library is a later edition from 2009. More importantly for our purposes, however, is that there is no information at all about the appearance of reader's marks in it, whereas the book is full of them (Figure 6).

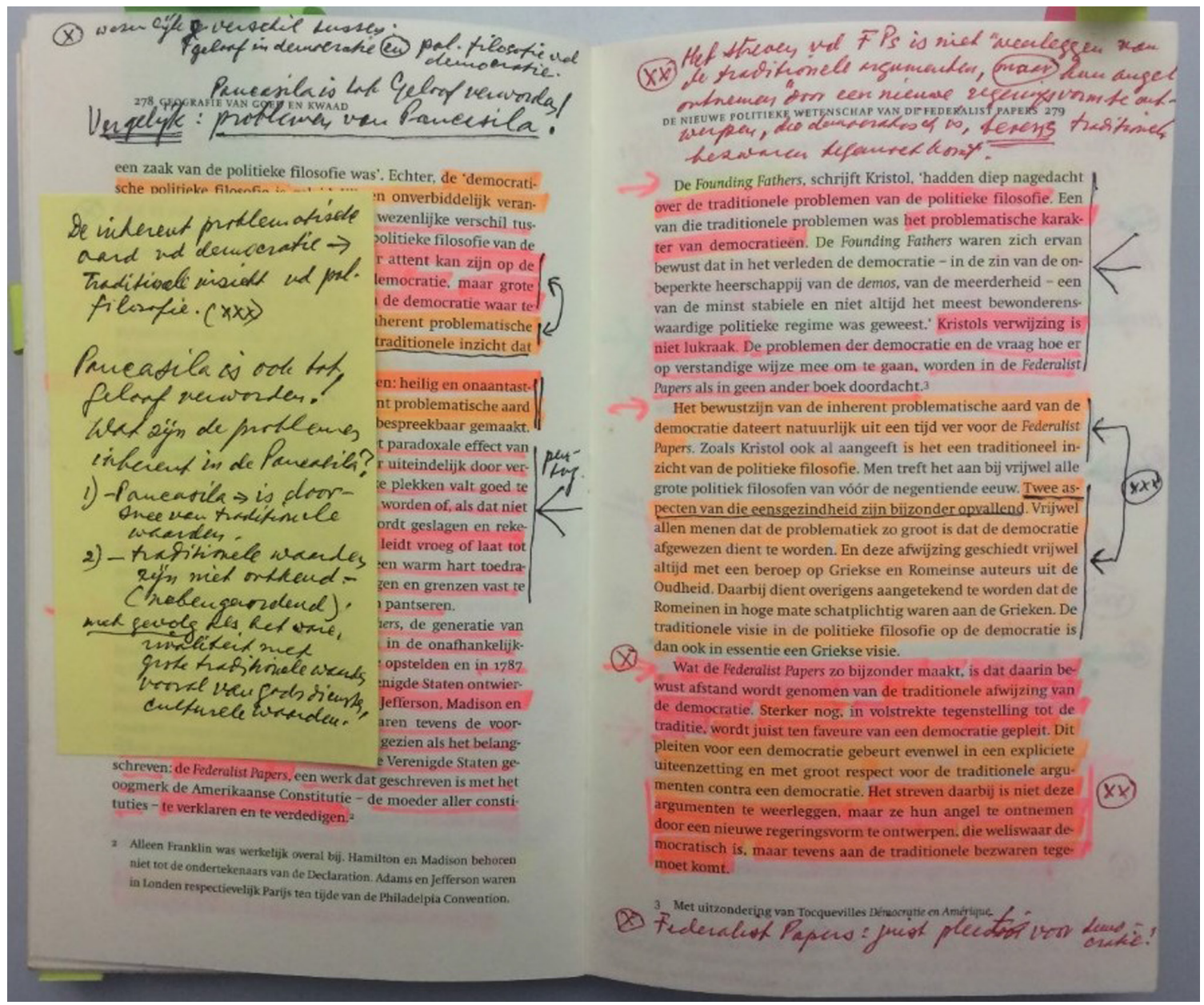

Figure 6. The remark in Kinneging (2009: 278) that democracy has degenerated into a belief prompted Mboi to comment (in Dutch) that Pancasila had also degenerated. (Perpustakaan Riset Ben Mboi Unika Atma Jaya, 170 KIN g). 
At the present stage, while many of Mboi's books are still waiting in cardboard boxes to be catalogued and put onto the shelves, I can merely offer some preliminary impressions. It is impossible for me to say when Mboi first started making marks in his books, but from what I have seen, the habit is most pronounced in his post-gubernatorial period when he developed an increasing interest in good governance. Books relating to this topic tend to be heavily marked in fluorescent highlighter; most of them were published in the early twenty-first century.

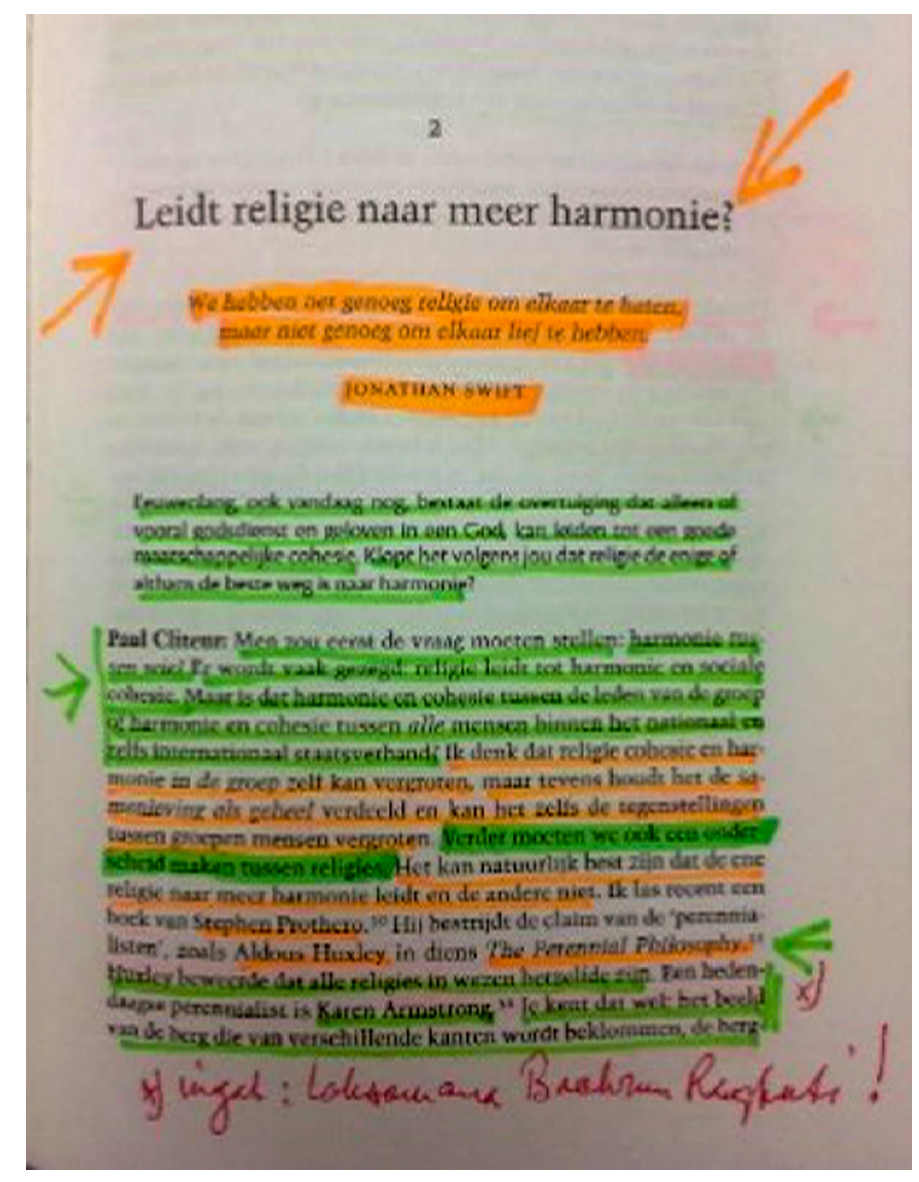

Figure 7. Beginning of the second chapter in Verhofstadt (2012: 29) on the question "Does religion lead to more harmony?" almost completely covered in green and orange. The passage on perennial philosophy reminded Ben Mboi of the Indonesian author Bahrum Rangkuti. (Perpustakaan Riset Ben Mboi Unika Atma Jaya, 201.6 VER g).

Most of Mboi's marks consist of so-called signs of attention (Jackson 2001: 28): the most basic signs are markings in fluorescent highlighter, often coupled with a vertical marginal line and an arrow or asterisk. The arrow functions as a modern-day form of the centuries-long popular manicule (Latin, meaning little hand), basically "the medieval version of a highlighter" (Burgess 2017). The asterisk refers to a note which is not inline. For example, in the second chapter of Verhofstadt (2012: 29), dealing with the question of whether religion will lead to more harmony, there is a passage on perennial philosophy, in which 
the interviewee, the Dutch humanist philosopher Paul Cliteur (born 1955), mentions the example of Karen Armstrong (born 1944; author of numerous books on religious affairs) as a contemporary perennialist. An asterisk in the margin refers to a note at the bottom of the page (Figure 7), in which Mboi has written: ingat: Laksamana Bachrum Rangkuti! (remember: Admiral Bachrum Rangkuti!). The latter person (1919-1977) was head of the Muslim pastoral service of the Indonesian navy and known in Indonesian literature for his Islamic writing, much influenced by the Urdu philosopher, poet and politician Muhammad Iqbal (1877-1938) (Salim HS 2012: 109).

This reference to an Indonesian author is also a good example of the way Mboi read his books, namely always with a view to the contemporary Indonesian situation. Among the many Dutch books that Mboi studied intensively is, for example, Van Beusekom (1933), which is a pre-war study about Dutch colonial provincial law and which hence seems to be antiquated and without much practical relevance for late twentieth-century Indonesia. ${ }^{38}$ Unfortunately, there is no information about when Mboi acquired it, but in all probability he must have been attracted to it due to its (historical) relevance to the issue of the authority of the provinces which suddenly received a new impulse at the end of the twentieth century when the system of centralized government was drastically altered (see Mboi 2011: 475-482 on decentralization policies). Although Van Beusekom's book deals with a topic that by then belonged to the colonial past, Mboi not only wrote many brief summaries (in Dutch) in the margins, but also made references to the post-colonial Indonesian situation. As is well-known, even though Dutch was replaced by Indonesian as the official language of the law after independence, the Dutch language still reverberates in the world of Indonesian jurists. It is surely for this reason that Mboi also paid close attention to the language in which the (provincial) law was formulated. For example, when Van Beusekom (1933: 83) writes about the differentiation in the (Dutch) constitution between vergadering (meeting) and zitting (sitting, assembly), Mboi provides the Indonesian equivalents, namely rapat and sidang.

Intriguingly, not only did Mboi read older Dutch literature from and dealing with the colonial period, but in the last years of his life especially he read many books by Dutch academics on topical issues in contemporary Dutch society, but without any discernible predilection for certain "leading lights" or particular schools of thought. For example, in Verhofstadt's above-mentioned 2012 book of interviews with Cliteur, the chapters on "the consequences of cultural relativism" (De gevolgen van het cultuurrelativisme); "towards a universal secular morality" (Naar een universele seculiere moraal); "freedom of speech" (Vrijheid van meningsuiting) and "towards a neutral government" (Naar een neutrale overheid) are almost completely highlighted in orange and green. However, an intriguing fact is that Mboi made regular references to

38 Incidentally, this is also an example of a book that is nowadays freely accessible online; for example via Utrecht University Repository, https:// dspace.library.uu.nl/handle/1874/311663 (accessed on 01-10-2018). 
Pancasila, the official Indonesian state philosophy, reacting to certain words, phrases, remarks or thoughts in a foreign text which - from the authorial perspective - had no intended connection to Indonesia at all. However, Mboi read his books from a decidedly Indonesian perspective, thereby creating his own meaning of a text. For example, in the Dutch translation of the Oxford professor and Christian theologian Alister McGrath's The Future of Christianity (McGrath 2007), the term "globalization", which is highlighted in orange, makes Mboi reflect on its effects in Indonesia (Figure 8). Whereas McGrath's text is very general, Mboi is most specific.

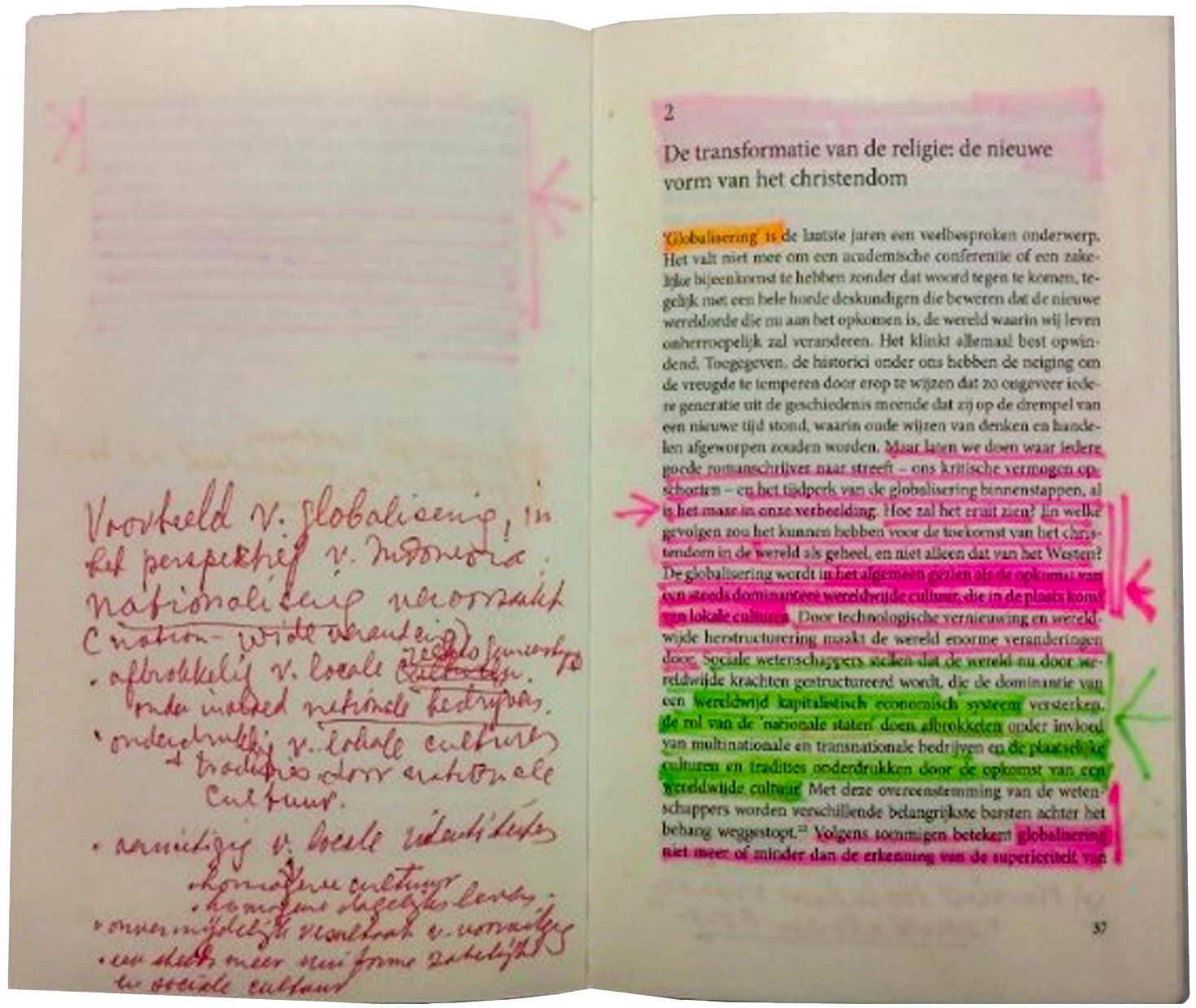

Figure 8. The first word "Globalisering" (Globalization), in McGrath (2010:37) makes Mboi reflect (in Dutch) on its effects in Indonesia. (Perpustakaan Riset Ben Mboi Unika Atma Jaya, 230.05 STR t).

\section{PANCASILA AND THE DUTCH PRISM}

Dutch publications functioned for Mboi as a prism, providing views of Indonesia through comparisons with Dutch phenomena as analysed by Dutch academics. For example, a compilation of sociological essays by the Dutch sociologist Kees Schuyt (2006) was studied intensively with the usual arsenal of arrows, highlightings and verbatim copies of phrases. Schuyt's book is very much concerned with problems troubling Dutch society, all relating to the 
question of how to cope with "newcomers", such as tensions between taxi drivers in Amsterdam or ethnic tensions in old neighbourhoods. Another burning subject is the coming of Islam, which has meanwhile become the second largest religion in The Netherlands. In this context Schuyt (2006: 39) also addresses the issue of freedom of religion, which has become highly topical due to the antagonism between what Schuyt (2009: 39) calls "fundamentalist believers and fundamentalist unbelievers". Surrounded by arrows, Mboi has copied Schuyt's (2006: 39-40) remark on the new religious conflict in The Netherlands: "not the truth or untruth of religious opinions should be the basis of practical political action, but the recognition of the right of everyone to live according to his own truth" (niet de waarheid of onwaarheid van de godsdienstige opvattingen dient uitgangspunt van praktisch staatkundig handelen te zijn, maar de erkenning van het recht van eenieder naar de eigen waarheid te leven). ${ }^{39}$ This is what Schuyt (2006: 40) views as the essence of religious freedom. Regrettably, Mboi does not comment upon its possible applicability in Indonesia.

A more historical study is Hans van den Heuvel's (2010) book on the morality of power, which was acquired by Mboi in Jakarta in 2011 and which is also full of markings in highlighter and marginal notes (call number $900 \mathrm{HEU}$ m). When Van den Heuvel (2010: 91) discusses a development in nineteenthcentury Dutch society whereby labourers and Calvinist kleine luyden (little people; an apt Indonesian translation would be wong cilik or orang kecil) strove for political influence and fought against poverty, social inequality and alcoholism by making use of the popular press, Mboi notes in the margin a parallel with contemporary Indonesia: Vergelijk de "Nasional-Demokrat" beweging na de Reformatie 1998 in Indonesia (Compare the "Nasional-Demokrat" movement after the 1998 reform era in Indonesia).

Mboi's life and work had mainly been shaped by Suharto's New Order. There are a number of telling anecdotes in his autobiography about his personal closeness to Indonesia's one-time strongman: when he was training as a parachutist for the Western New Guinea operation, his group was commanded by Suharto, and a few years later, in 1964, Suharto, who was then still an unassuming general commanding Kostrad (Komando Strategis Angkatan Darat, Army Strategic Reserve Command) and not yet Indonesia's longest serving president, gave him a "big Philips radio" as a wedding gift (Mboi 2011: 487). Mboi also enjoyed good relations with other key players of the New Order. Unsurprisingly, Mboi did not greet Suharto's ousting with joy and viewed the post-Suharto era after 1998 as a highly problematic period. The East Timorese independence referendum of 1999, which subsequently led to the creation of the new sovereign state of the Democratic Republic of TimorLeste, was in Mboi's eyes a "political blunder" and a "failure of statesmanship and statecraft" (Mboi 2011: 274, 277).

39 Schuyt (2006) has been given the call number $301 \mathrm{SCH}$ s, but due to the classification system of Atma Jaya Library, this same number is used for Schneider (1975), which also belongs to the category of sociology (301) and has an author's name beginning with $\mathrm{SCH}$, while the "s" stands for the first word of the title. 
In several books in Mboi's collection from the post-Suharto period one may find negative asides on vaguely defined ideas of reformasi (reform) which happened to be the buzzword of that era (which still continues today). When Pope John Paul II in his last book commented that after the fall of Marxism the states of the former Soviet bloc faced "the problem of liberalism" (John Paul II 2005: 46), Mboi notes on the opposite page (in English): "Indonesia post-New Order $\rightarrow$ problem of liberalism", remarking on the following page (John Paul II 2005: 48) “Compare 'Reformasi' 1998 in Indonesia which was only 'a negative movement', 'no clear positive ideals'" (call number 242 PAU $\mathrm{m})$. Incidentally, "liberalism" almost always has negative connotations in the history of postcolonial Indonesian discourse, in which "freedom" is viewed with suspicion. When the Dutch historian Hermann W. von der Dunk (2011: 11) makes a general remark that it is normal to view contemporary problems and threats as new and hence bigger than those of the past, Mboi draws in the margin the parallel "Orde Baru vs Orde Reformasi" (call number 900 DUN $\mathrm{g}$; date of acquisition unknown).

Mboi must have read many books in the post-Suharto years; not just Dutch but also English and Indonesian publications. Another papal book, this time by Joseph Ratzinger or Pope Benedict XVI, on Jesus of Nazareth (in English translation), which was acquired in Jakarta on 4 November 2007, was also read intensively, as is evidenced by many markings in highlighter, but with few annotations. Apart from its relevance to Mboi's faith, aspects of governance seem to have attracted his attention especially: for example, when Ratzinger (2007: 124) writes "And the fact of the matter is that social order has to be capable of development", Mboi notes in the margin (in English): "a social order has to be capable of development (pol. order, econ. order, et cetera)", while on the next pages he makes brief notes on law and "rules vs principles" (call number $232.901 \mathrm{BEN} \mathrm{j}$ ).

In the post-Suharto period, Pancasila occupied a pivotal role in Mboi's thinking about good governance. This is hardly surprising, taking into consideration that Pancasila is at the very centre of Indonesian political discourse. Mboi's autobiography contains many reflections upon its importance for Indonesian society: at the beginning of his memoirs, he explains that Pancasila is a unique "existential philosophy" (falsafah eksistensial) that is fully consonant with the "philosophy of life" of the Manggarai people and indeed with traditional concepts of the world shared by all other Indonesian peoples. However, it is also deemed to be compatible with modern political ideologies, both of the left and the right (Mboi 2011: 38-41). In the epilogue, expressing his hopes and good wishes, he once more emphasizes the need for a theoretical rethinking of Pancasila (Mboi 2011: 559).

In a collection of philosophical essays by the Dutch legal philosopher Andreas Kinneging, Geografie van goed and kwaad (The geography of good and evil, 2009), Mboi has studied several chapters intensely. The remark in Kinneging (2009: 278) that democracy has degenerated into a belief prompted Mboi to write (in Dutch) at the top of the page that Pancasila had 
also degenerated into a belief, drawing a parallel to the problems concerning Pancasila. He added a yellow sticky note repeating that Pancasila had degenerated into a belief, summing up some of its problems. The related section of Kinneging's book on democracy is marked in the margin as "important" (using the Indonesian word penting) (Figure 6).

In another book, marked "Jkt 2008", namely Paul Frissen's 2007 monograph on the tension between equality and diversity in The Netherlands, Mboi has also left his marks on almost every page. This book, too, is read against the Indonesian foil of Pancasila: for example, Frissen's statement that according to much political theory, the goal of politics should be the implementation of a just society (Frissen 2007: 211) triggered Mboi into asking whether Indonesian politics has articulated "the good society" (Figure 9). Mboi thinks that Pancasila has done this ("yes"), but there is still no agenda to realize this "Pancasila society" ("no").

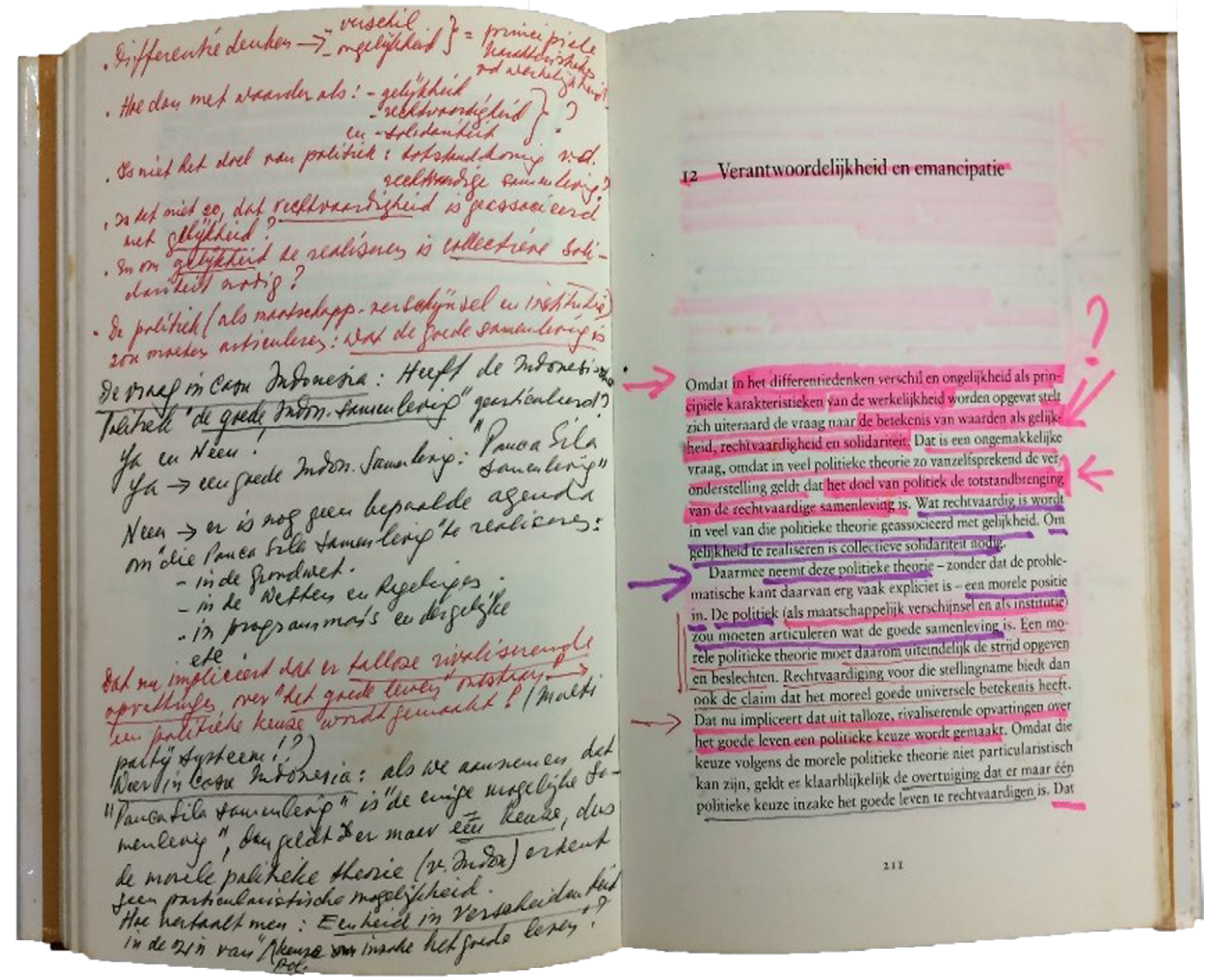

Figure 9. On page 210 of Frissen (2007) Mboi discusses Pancasila, taking up Frissen's statement on p. 211 (line 6) that according to much of political theory, "the goal of politics is the implementation of the just society" which is also marked with an arrow. (Perpustakaan Riset Ben Mboi Unika Atma Jaya, 320.5 FRI s). 
Elsewhere in Frissen's book, Mboi draws further parallels with the Indonesian situation, repeatedly citing not only Pancasila but also Sumpah Pemuda (Youth Oath of 1928). On page 164 of Frissen's book, Mboi praises Pancasila as the "genius" of Soekarno who thereby knew how to unite all groups in society despite the lack of ideological agreement among them; but according to Mboi, Indonesian public administration never formulated a way to manage this plurality, so that the official national motto of Indonesia, namely "unity in diversity", remained a slogan, merely emphasizing "unity". When Frissen (2007: 38) remarks that "The Netherlands" have never become "a political idea", but are perhaps at best merely a feeling which some Dutch people may have upon returning from abroad or when reading a book about the Golden Age, Mboi notes in the margin: "Has 'Indonesia' also already become 'our political idea' or not? Or is behind it just 'me' or 'my group'?" (Apakah "Indonesia" juga telah menjadi "idee politik kita" atau belum? Atau di balik itu malahan "saya"? atau "kelompok saya"?).

It is interesting to observe here that Mboi writes this comment in Indonesian, whereas elsewhere in this book his notes are in Dutch. Why is this? A possible explanation could be that the matter was so important to him that he automatically used his nation's language. In his autobiography, Mboi (2011: 159) recalls that he once had a discussion in Dutch with a Dutchman who stated that he found it remarkable that Mboi switched directly from Dutch to Malay/Indonesian as soon as the topic of conversation turned to Western New Guinea. Mboi (2011: 160) gave the following explanation for this in Dutch: "Because I speak about my right, I must speak in my own language, so that I do not make mistakes concerning my right" (Want ik spreek over mijn recht, ik moet in mijn eigen taal spreken, zodat $i k$ geen fouten maak betreffende mijn recht). This is a very legalistic position, as if Mboi was defending Indonesian rights in a court of law. By contrast, my interpretation would be of a more psychological nature: polyglots tend to return to their mother tongue "when expressing strong affects" (Seeman 2016: 195), whereas normally "[o]ne's second language serves more defensive purposes and is seen as the language of rationality" (Seeman 2016: 195)..$^{40}$ Western New Guinea was close to Mboi's heart and I think the same was true of his idea of "Indonesia", hence Indonesian was his "natural" choice.

\section{ELITISM OR NOBLESSE OBLIGE}

In a speech in Kupang on 6 April 2009 on the occasion of the launch of his book Ben Mboi berbicara tentang agama, pemerintahan dan pembangunan (Ben Mboi speaks about religion, administration, and development), Mboi addressed the topic of "NTT dan keterpanggilan para elite Flobamora" (NTT and the calling of the elite of Flora, Sumba, Timor, and Alor). This motivational text, which was not intended as an academic publication, is not burdened by bibliographical references and footnotes, but apparently one of the sources

40 Note, however, that Seeman (2016) discusses patients in therapy; but I think her observations can be generalized here. 
that Mboi used was a Dutch book on the role of the elite in society by Krijn van Beek and Marcel Ham (eds), Gaat de elite ons redden? De nieuwe rol van de bovenlaag in onze samenleving (Amsterdam: Van Gennep, 2007; call number 362 BEE 9). The title translates "Will the elite save us? The new role of the upper class in our society". This book bears Ben Mboi's name and "Jkt 2008" at the beginning. The first forty pages and pages 139-158 are covered with markings in fluorescent highlighter pens and some of the terms used there apparently inspired Mboi, such as the distinction between the "thinking" and the "acting" elites (see Van Beek and Ham 2007: 15). Mboi not only highlighted both terms and specifically pointed to them with arrows, but also copied them verbatim in his own handwriting in ink (Figure 10). In his own text, Mboi (2009a: 390) adopted the idea of the two kinds of elite as follows: "Speaking in a general way, it could be said that the people of NTT need two kinds of elite: firstly, an elite of thinkers (denkende elite, 'thinking elite') and secondly, an elite of doers (handelende elite, 'doing elite')". ${ }^{41}$ The slogan noblesse oblige, which is translated into Dutch as adel verplicht (Van Beek and Ham 2007: 14), is also highlighted and was adopted by Mboi in his text (Mboi 2009a: 383, 388).

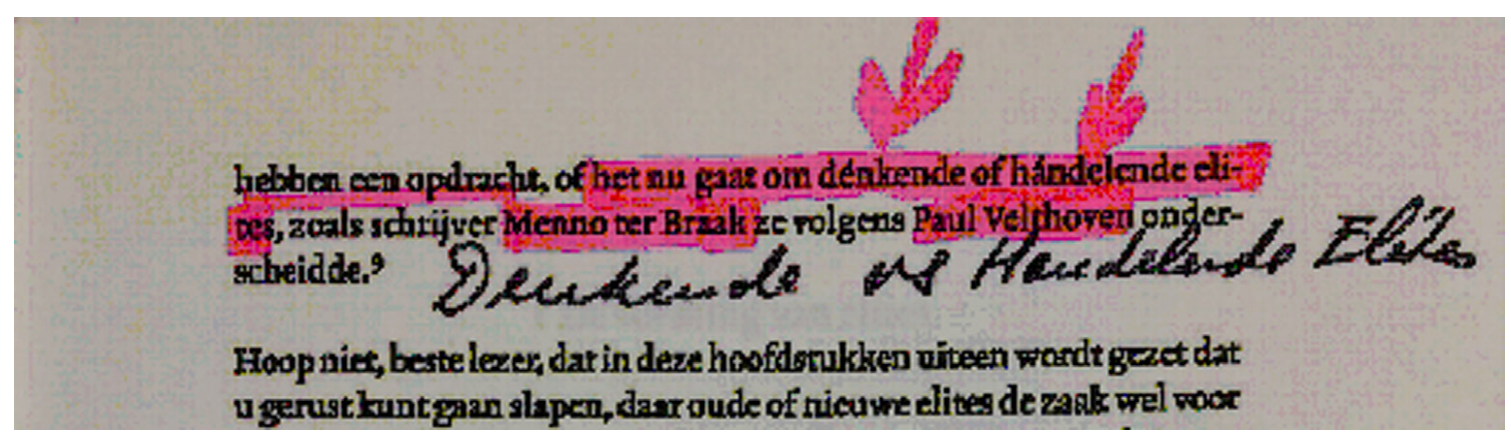

Figure 10. Ben Mboi not only highlighted the terms "thinking" and "acting" elite with arrows and pink fluorescent highlighter, but also repeated them in his own writing. Detail from the top of Van Beek and Ham (2007: 15). (Perpustakaan Riset Ben Mboi Unika Atma Jaya, 362 BEE g).

In contrast to the critical views of Dutch academics assembled in Van Beek and Ham's 2007 book, elitism was not a negative concept for Mboi (2011), who in his autobiography repeatedly refers to it with high praise. The expression noblesse oblige also appears in his memoirs where it is said to be consonant with local Manggarai philosophy that he had learned from his father (Mboi 2011: 75). Mboi uses the term falsafah kekraengan which could be translated as "aristocratic philosophy", that was instilled in him by his (aristocratic) father, teaching that "elitism is not a privilege, elitism is a responsibility!" (Mboi 2011: 76). The same idea is expressed (in English) by Mboi in a similar statement uttered in his acceptance speech of the Magsaysay Award in 1986, which now adorns the entrance wall of the library at Atma Jaya that bears his

${ }_{41}$ "Bicara secara umum dapat dikatakan bahwa rakyat NTT membutuhkan dua jenis Elite: pertama, Elite Pemikir (denkende Elite, thinking Elite) dan kedua, Elite Pelaku (handelende Elite, doing Elite)" (emphasis in the original). 
name: "Leadership is a blessing. It is a calling, it is a privilege, it is an honor. At the same time it is a responsibility and a challenge" (see also Mboi 2011: 497).

The chapter on the "old boys' network" in the Netherlands in Van Beek and Ham's book (2007: 19-38) also attracted Mboi's attention, as is testified by many coloured markings, and it seems to have inspired him to include a remark in his 2009 Kupang speech about the "modern elite" as a "network elite" (Mboi 2009a: 387). However, unlike the rather critical Dutch contribution which points out the risks and dangers of an "old boys' network", Mboi (2009a: 387), who refrains from using the latter term, views a "network elite" as something positive for NTT, expressing the aspect that the people concerned work together as a collective and not as individuals. I suspect that Mboi avoided using the expression "old boys' network" on purpose, because it is basically synonymous with cronyism, and one of the promises of reformasi was to get rid of Suharto's legacy of KKN which stands for corruption, collusion and nepotism (korupsi, kolusi, nepotisme). Rather than pleading for favouritism of family and friends, Mboi emphasized the importance of the key terms kebersamaan (community; sense of togetherness) and gotong royong (working together in mutual cooperation) (Mboi 2009a: 387). This is fully in accordance with the ideal of "togetherness" as a leading theme in many other speeches which Mboi made over the years. ${ }^{42}$

In an unpublished conference paper submitted in 2009, Mboi (2009b: 17) states that when he first became Governor of NTT, he started reading a host of literature by Dutch ethnologists and civil servants (all from the colonial era), among others De Kat Angelino's two-volume handbook on colonial policy from 1929-30, which was considered as the "Bible of civil servants in the Dutch Indies". In his autobiography, Mboi (2011: 473-474) is very enthusiastic about this handbook. This transfer of ideas about administration is most intriguing, because here we have an example of a postcolonial Indonesian politician whose nationalist credentials are unquestioned but who at the same time has no qualms about mentioning the influence of someone like De Kat Angelino, who was a theorist of efficacious colonial government. This might seem surprising: is it a case of old wine in new bottles? Should the colonial/ postcolonial divide not reflect fundamental changes in policies and practices?

Arnold Dirk Adriaan de Kat Angelino (1891-1969) was a civil servant whose massive two-volume semi-official apologist work on Dutch colonial rule, sponsored by the Ministry of Colonial Affairs, became the 'Holy Bible of the official mind' (Gouda 1995: 40)..$^{43}$ As a contemporaneous critic remarked, it was 'a handbook for the colonial leader" ("een handbook voor den koloniale leider", Stokvis in 1931 cited in Gouda 1995: 251). Mboi had no less than three copies of De Kat Angelino's work (that is to say duplicates, all with the call number

42 For example, Mboi's collection of speeches opens with Kesetiaan: kunci kebersamaan (Loyalty: the key to togetherness) from 1979 (Mboi 2009a: 1-11) and Mbangun kebersamaan (Developing togetherness) from 1981 (Mboi 2009a: 12-19); but many other texts in this book also have bersama (together) in the title.

${ }_{43}$ A short biography can be found in Drooglever (2013). 
354.91 KAT s), but he did not make many notes in them, with the notable exception of the chapter on 'The calling of leadership' (De roeping van het leiderschap, De Kat Angelino 1929: 83-142). De Kat Angelino's expression 'The calling of leadership' may have struck a chord with Mboi, because it is strongly religiously laden, with Biblical echoes that only the elect will experience the calling (for example Matthew 22: 14 "For many are called, but few are chosen") - in short, a very elitist point of view. It is surely no coincidence that Mboi, in respect of the above-mentioned slogan on leadership which was chosen as the motto of the research library at Atma Jaya that bears his name, liked to call leadership "a calling" and used the same terminology in his 2009 speech about the "calling of the elite" of NTT (Mboi 2009b). Without the slightest embarrassment, then, a member of the dominant elite propounded a selfaffirmative position, thinking highly of the class to which he himself belongs and which is said to pursue the greater good of all.

Although De Kat Angelino was a passionate advocate of the colonial regime, his attraction for the postcolonial Indonesian nationalist elite must have been his rather illiberal ideas on collectivism for the greater good of "the people". As Gerry van Klinken (2003: 40) points out, "Religiously oriented 'organic' concepts of statecraft have often been promoted by ruling elites. They put a premium on stability, justify rule by the few and acquiescence by the many, put a moral gloss on repressive practices and the maintenance of the status quo. They retained their attraction for ruling circles in Indonesia into the Suharto era".

One might even add that this continued well into the post-Suharto period and is still central in the ongoing Pancasila discourse today. For example, as recently as August 2018, Anwar Arifin published his book Pancasila: Ideologi tengah tanpa oposisi (Pancasila: Ideology of the centre without opposition), in which basically the same ideas are presented as by Mboi: this is a tiny elite's groupthink which, however, still dominates Indonesian political debates. Anwar Arifin, born in Sengkang, South Sulawesi, in 1947, and who is descended from Buginese aristocracy (the "Andi" line to which Nafsiah Mboi also belongs), is a professor of politics but also a fervent supporter of Golkar (Golongan Karya) or Functional Work Group; also the political party of Ben and Nafsiah Mboi, which was set up during the New Order as one of its key institutional pillars, winning every election in the Suharto era. Arifin (2018) voices the same thoughts as Mboi about the compatibility of Pancasila with the persuasions and party affiliations of all Indonesians. Arifin (2018: 80) also glosses the ideal of gotong royong (mutual cooperation) as kekeluargaan (family spirit; brotherhood) - a term derived from keluarga or family - which is said to be deeply rooted in Indonesian society.

This idea of the Indonesian state as a primordial community based upon (family) solidarity is very appealing to the authoritarian Indonesian oligarchy. As David Bourchier (2015: 234) explains, notions such as "integralism" and the "family state" which stress togetherness, unity and oneness, are characteristic of Suharto's New Order. Although the integralist ideology likes to harp on age-old indigenous traditions, according to Bourchier (2015: 234) it is "best 
understood in the wider context of the organicist tradition of romantic nationalist thought". Yet the integralist ideology still has a strong hold on post-Suharto Indonesia, and Bourchier (2015: 234) correctly warns against dismissing its ideas of the ideal Indonesian state as "meaningless relics of a bygone era". The materials collected by Ben Mboi, but also his comments upon them, will continue to remain relevant.

\section{REFERENCES}

ahy/mok. 2011. "Rumah Bung Hatta; Antara sejarah dan beban biaya", detiknews 7 January 2011. [Retrieved from: https://news.detik.com/ berita/1541309/rumah-bung-hatta-antara-sejarah-dan-beban-biaya; accessed on 23-08-2018.]

Anonymous. 2010. "Bung Hatta dan bukunya", Anarchy Blog 26 September 2010. [Retrieved from: http:/ / dimasanarky.blogspot.com/2010/09/bnghatta-dan-bukunya.html; accessed on 23-08-2018; Said to be taken from Kompas, 17 September 2007.]

Archer, Jeffrey. 1998. The eleventh commandment. London: HarperCollins Publishers.

Arge, Rahman. 2008. 200 kolom pilihan permainan kekuasaan. Jakarta: Penerbit Buku Kompas.

Arifin, Anwar. 2018. Pancasila; Ideologi tengah tanpa oposisi. Jakarta: Nufa Citra Mandiri.

Arps, Bernard. 1999. "How a Javanese gentleman put his library in order", Bijdragen tot de Taal-, Land-en Volkenkunde Vol. 155(3): 416-469.

Beck, Ulrich. 1997. The reinvention of politics; Rethinking modernity in the global social order. Cambridge: Polity Press.

Beek, Krijn van and Marcel Ham (eds). 2007. Gaat de elite ons redden? De nieuwe rol van de bovenlaag in onze samenleving. Amsterdam: Van Gennep.

Behrend, Timothy E. 1988. "Small collections of Javanese manuscripts in Indonesia", Archipel Vol. 35: 23-42.

Beusekom, Johan van. 1933. De Indische provincie; Inleiding tot het NederlandschIndisch provinciaal recht. Groningen/Den Haag/Batavia: Wolters.

Bibang, Gerard N. 2015. "[Narasi 100 hari Ben Mboi] Seluas-luas cakrawala". [Retrieved from: http://www.floresa.co/2015/10/14/narasi-100-hariben-mboi-seluas-luas-cakrawala/; accessed on 24-09-2018.]

Bohlens, Klaas. 1983. Tennis; Training, techniek, taktiek. Rijswijk: Elmar.

Bourchier, David. 2015. Illiberal democracy in Indonesia; The ideology of the family state. London/ New York: Routledge.

Burgess, Anika. 2017. "For centuries, readers annotated books with tiny drawings of hands", Atlas Obscura 23 August 2017. [Retrieved from: https://www.atlasobscura.com/articles/manicules; accessed on 26-082018.]

Cayne, Bernard et al. (eds). 1986. The Encyclopedia Americana. International edition. Volume 1. Danbury: Grolier.

Clancy, Tom. 1988. The cardinal of the Kremlin. London: Collins. 
Cortesão, A. and A. Teixeira da Mota (eds). 1960. Tabularum Geographicarum Lusitanorum Specimen. Olisipone [Lisbon].

Dawis, Aimee. 2012. "Sidharta, Myra", in: Leo Suryadinata (ed.), Southeast Asian personalities of Chinese descent; A biographical dictionary. Volume 1, pp. 973-975. Singapore: Institute of Southeast Asian Studies.

D'Haen, Theo (ed.). 1990. Herinnering, herkomst, herschrijving; Koloniale en postkoloniale literaturen. Leiden: Vakgroep Talen en Culturen van ZuidoostAzië en Oceanië, Rijksuniversiteit Leiden.

Dijk, Kees van and Jean Gelman Taylor. 2011. Cleanliness and Culture: Indonesian histories. Leiden: KITLV Press.

Drooglever, P.J. 2013. “Kat Angelino Arnold Dirk Adriaan de (1891-1969)", Biografisch Woordenboek van Nederland. [Retrieved from: http:/ / resources. huygens.knaw.nl/bwn1880-2000/lemmata/bwn3/kat; accessed on 2408-2018.]

Duarte, Teófilo. 1930. Timor (Ante-camara do inferno!?). Famalicão: Tip. Minerva de Gaspar Pinto de Sousa \& Irmão.

Dunk, H.W. von der. 2011. De glimlachende sfinx; Kernvragen in de geschiedenis. Amsterdam: Bert Bakker.

Duverger, Maurice. 1979. The study of politics. Sunbury-on-Thames: Nelson.

Edwards, Nicola. 2013. "Values and the institutionalization of Indonesia's organic agriculture movement", in: Michele Ford (ed.), Social activism in Southeast Asia, pp. 72-88. London/New York: Routledge.

Fleishman, Joel L., Lance Liebman, and Mark H. Moore. 1981. Public duties; The moral obligations of government officials. Cambridge, Mass. / London: Harvard University Press.

Fox, James J. (ed.). 1980. The flow of life; Essays on Eastern Indonesia. Cambridge, Mass. / London: Harvard University Press.

Fraser, Neale. 1975. Successful Tennis; From beginner to expert in forty lessons. London: Pelham Books.

Frissen, P.H.A. 2007. De staat van verschil; Een kritiek van de gelijkheid. Amsterdam: Van Gennep.

Gallop, Annabel Teh. 2014. "Indonesian and Malay manuscripts in the Endangered Archives Programme". [Retrieved from: http://blogs.bl.uk/ asian-and-african/2014/02/indonesian-and-malay-manuscripts-in-theendangered-archives-programme.html; accessed on 23-08-2018.]

Gallop, Annabel Teh. 2018. "Shifting landscapes: mapping the intellectual writing traditions of Islamic Southeast Asia". [Retrieved from: http:// blogs.bl.uk/asian-and-african/2018/02/shifting-landscapes-mappingthe-intellectual-writing-traditions-of-islamic-southeast-asia.html; accessed on 23-08-2018.]

Gerrits, André. 2006. Democratie door interventie; De nieuwe white man's burden? Amsterdam: Amsterdam University Press.

Gobée, E. and C. Adriaanse. 1990-1995. Nasihat-nasihat C. Snouck Hurgronje semasa kepegawaiannya kepada pemerintah Hindia Belanda 1889-1936. Vols I-XI. Jakarta: INIS. 
Gouda, Frances. 1995. Dutch culture overseas; Colonial practice in the Netherlands Indies, 1900-1942. Amsterdam: Amsterdam University Press.

Greenhill, J.P. 1955. Obstetrics. Eleventh edition. Philadelphia, PA / London: W.B. Saunders Company.

Griebeler, Monika. 2015. "Literature in Indonesia; A land without readers", Qantara.de 29 May 2015. [Retrieved from: http:/ / en.qantara.de/content/ literature-in-indonesia-a-land-without-readers; accessed on 23-08-2018.]

Gunawan S., Arif. 2016. "Indonesia second least literate of 61 nations", The Jakarta Post 12 March 2016. [Retrieved from: http:/ / www.thejakartapost. com/news/2016/03/12/indonesia-second-least-literate-61-nations.html; accessed on 23-08-2018.]

Hay, Roy. 1975. Home E city gardener. London: Octopus Books.

Heuvel, Hans van den. 2010. Moraal van de macht; Historisch portret van de integriteit van de staat. Zutphen: Walburg Pers.

Hoogervorst, Tom. 2017. “Books written for everyone (and protected by a few $)^{\prime \prime}$. [Retrieved from: http://www.kitlv.nl/blog-books-writteneveryone-protected/; accessed on 11-09-2018.]

Jackson, H.J. 2001. Marginalia; Readers writing in books. New Haven, CT: Yale University Press.

John Paul II. 2005. Memory and identity; Personal reflections. London: Weidenfeld \& Nicolson.

Johnson, Hugh. 1988. Hugh Johnson's pocket encyclopedia of wine 1989. New York: Simon \& Schuster.

Kat Angelino, A.D.A. de. 1929. Staatkundig beleid en bestuurszorg in NederlandschIndië; Eerste Deel: Grondslagen en richtlijnen van koloniaal beleid. Eerste gedeelte. 's-Gravenhage: Nijhoff.

Kieboom, Hilde. 2005. Een hart voor deze tijd; Christen zijn vandaag. Tielt: Lannoo.

Kinneging, Andreas. 2009. Geografie van goed en kwaad; Filosofische essays. Houten: Spectrum. [First edition 2005.]

Klinken, Gerry van. 2003. Minorities, modernity and the emerging nation; Christians in Indonesia, a biographical approach. Leiden: KITLV Press.

Kramer, R. 1984. Inventaris van het archiefvan de Ronde Tafel Conferentie Indonesië, 1949 (1950). Den Haag: Nationaal Archief. [Retrieved from: http:/ / www. gahetna.nl/collectie/archief/pdf/NL-HaNA_2.10.38.ead.pdf; accessed on 31-08-2018.]

Kuitenbrouwer, Maarten. 2014. Dutch scholarship in the age of empire and beyond; KITLV - The Royal Netherlands Institute of Southeast Asian and Caribbean Studies, 1851-2011. Leiden/ Boston: Brill.

Kurniawan, Hasan. 2015. "Mohammad Hatta, buku dan revolusi Indonesia", Sindonews.com 25 July 2015. [Retrieved from: https:/ / daerah. sindonews.com/read/1026080/29/mohammad-hatta-buku-dan-revolusiindonesia-1437772580; accessed on 23-08-2018.]

Lach, Donald F. and Edwin J. van Kley. 1993. Asia in the making of Europe. Volume III: A century of advance. Book Three: Southeast Asia. Chicago/London: University of Chicago Press. 
Leitão, Humberto. 1948. Os Portugueses em Solor e Timor de 1515 a 1702. Lisboa: Tip. da Liga dos Combatentes da Grande Guerra.

Luitnan, Ishak Arries. 2012. Koepang tempo doeloe. Depok: Penerbit Ruas.

Martin, Hans-Peter and Harald Schumann. 1996. Die Globalisierungsfalle. Der Angriff auf Demokratie und Wohlstand. Reinbeck: Rowohlt.

Massier, Ab. 2008. The voice of the law in transition; Indonesian jurists and their languages 1915-2000. Leiden: KITLV Press.

Mboi, Ben 2005. “RPKAD vs KKO”, in: Triantoro, Bambang (ed.), L.B. Moerdani: langkah dan perjuangan, pp. 115-120. Jakarta: Yayasan Pengembangan Tunas Nusa.

Mboi, Ben. 2007. Berpikir, berbicara dan berbuat untuk rakyat dan daerah Nusa Tenggara Timur. Himpunan pidato pilihan selama 10 tahun menjadi gubernur NTT. Kupang: Penerbit Gita Kasih.

Mboi, Ben. 2009a. Berbicara tentang agama, pemerintahan dan pembangunan. Kupang: Penerbit Gita Kasih.

Mboi, Ben. 2009b. “Sekelumit 'sejarah' terbentuknya Propinsi Nusa Tenggara Timur; Flobamora di tengah persendian paruh abad pertama dan kedua Nusa Tenggara Timur menatap paruh-abad kedua 2008-2058". [Paper, International workshop and seminar "Sustainable Development Strategy for the Secondary Cities", Pangkalpinang, Bangka, 20-22 April.]

Mboi, Ben. 2011. Ben Mboi; Memoar seorang dokter, prajurit, pamong praja. Jakarta: Kepustakaan Populer Gramedia.

Meij, Dick van der. 2017. Indonesian manuscripts from the islands of Java, Madura, Bali and Lombok. Leiden/Boston: Brill.

McGrath, Alister. 2010. De toekomst van het christendom. Kampen: Kok.

Moeimam, Susi and Hein Steinhauer. 2005. Kamus Belanda-Indonesia. Jakarta: Gramedia Pustaka Utama.

Moreels, Lod. (ed.). 1976. Jan van Ruusbroec; Vanden VII sloten of een dag contemplatief leven en werken. Amsterdam/Tielt: Lannoo.

Murphy, Francis D. et al. 1958. Medical emergencies; Diagnosis and treatment. Philadelphia, PA: F.A. Davis Company.

Nieuwenhuijsen, Peter. 1985. Gemeenten als proeftuin voor een houdbare verzorgingsstaat. Deventer: Van Loghum Slaterus.

Oei, Tjien and H.G. Kwee. 2010. Memoirs of Indonesian doctors and professionals; 2. Bloomington, IN: Xlibris Corporation.

Poczter, Sharon and Thomas B. Pepinsky. 2016. "Authoritarian legacies in post-New Order Indonesia; Evidence from a new dataset", Bulletin of Indonesian Economic Studies 52(1): 77-100.

Price, Leah. 2008. "When to read was to write. Review of used books; Marking readers in renaissance England, by William H. Sherman", in: London Review of Books 30(19): 35-37. [Retrieved from: https://core.ac.uk/download/ pdf/28931970.pdf; accessed on 24-08-2018.]

Ratzinger, Joseph. 2007. Jesus of Nazareth; From the baptism in the Jordan to the transfiguration. London/New York/Berlin: Bloomsbury.

Rempah, Jalur. 2017. “Quo vadis, Indonesian literacy?", The Jakarta Post 12 
November 2017. [Retrieved from: http://www.thejakartapost.com/ adv/2017/11/12/quo-vadis-indonesian-literacy.html; accessed on 2308-2018.]

Roque, Ricardo Nuno Afonso. 2010. Headhunting and colonialism; Anthropology and the circulation of human skulls in the Portuguese empire, 1870-1930. Houndmills: Palgrave Macmillan.

Rose, Mavis. 2010. Indonesia Free; A political biography of Mohammad Hatta. Jakarta/Kuala Lumpur: Equinox Publishing.

Rowling, J.K. 2001. Harry Potter and the philosopher's stone. London: Bloomsbury. Salim HS, Hairus. 2012. "Indonesian Muslims and cultural networks", in: Jennifer Lindsay and Maya Liem (eds), Heirs to world culture; Being Indonesian 1950-1965, pp. 75-118. Leiden: KITLV Press.

Schneider, Louis. 1975. The sociological way of looking at the world. New York etcetera: McGraw-Hill.

Schulte Nordholt, H. 1990. Onderzoek in Zuidoost-Azi; Agenda's voor de jaren negentig. Leiden: Vakgroep Talen en Culturen van Zuidoost-Azië en Oceanië, Rijksuniversiteit Leiden.

Schuyt, Kees. 2006. Steunberen van de samenleving; Sociologische essays. Amsterdam: Amsterdam University Press.

Seeman, Mary V. 2016. "Bilingualism and schizophrenia", World Journal of Psychiatry 6(2): 192-198.

Seifert, Alwin. 1972. Tuinieren zonder gif al dan niet volgens de biologischdynamische methode. Baarn: Hollandia.

Sheinwold, Alfred. 1968. Bridge play. New York, NY: Cornerstone Library.

Sidharta, Myra. 2011. "Menggali kembali sastra Melayu Tionghoa". [Retrieved from: http:// web.budaya-tionghoa.net/index.php/item/791-menggalikembali-sastra-melayu-tionghoa; accessed on 11-09-2018.]

Skera, Frans X. and Mundus Lema. 2013. Flobamora kemarin, hari ini \& esok; Himpunan pemikiran kritis cerdas para tokoh NTT. Kupang: Penerbit Gita Kasih.

Smith, Karen Houston. 2011. "Leadership and leader, governance and governor NTT 1978-1988", in: Candra Gautama (ed.), Liber amicorum voor Ben Mboi, leermeester voor velen, pp. 7-13. Jakarta: Kepustakaan Populer Gramedia.

Steenbrink, Karel. 2013. "Dutch colonial containment of Islam in Manggarai, West Flores, in favour of Catholicism, 1907-1942", Bijdragen tot de Taal-, Land-en Volkenkunde Vol. 169(1): 104-128.

Stein, Eric A. 2009. "'Sanitary makeshifts' and the perpetuation of health stratification in Indonesia", in: Robert A. Hahn and Marcia C. Inhorn (eds), Anthropology and public health; Bridging differences in culture and society, pp. 541-565. Second edition. Oxford: Oxford University Press.

Subhan, Ahmad. 2012. "Save PDS H.B. Jassin; Social movement for the cultural heritage". [Paper, Congress of Southeast Asian Librarians XV, Denpasar, Bali, 28-31 May; Retrieved from: https://www.researchgate. net/publication/315884710_Save_PDS_HB_Jassin_Social_Movement_ for_the_Cultural_Heritage; accessed on 23-08-2018.] 
Swantoro, P. 2002. Dari buku ke buku, sambung menyambung menjadi satu. Jakarta: Kepustakaan Populer Gramedia.

Tebay, Neles. 2009. Dialog Jakarta-Papua; Sebuah perspektif Papua. Jakarta: SKP Jayapura.

Triantoro, Bambang (ed.). 2005. L.B. Moerdani: langkah dan perjuangan. Jakarta: Yayasan Pengembangan Tunas Nusa.

Vatikiotis, Michael R.J. 1993. Indonesian politics under Suharto; Order, development and pressure for change. London/New York: Routledge.

Verhofstadt, Dirk. 2012. In gesprek met Paul Cliteur; Een zoektocht naar harmonie. Antwerpen/Utrecht: Houtekiet.

Vermeulen, Gerret. 1677. De gedenkwaerdige voyagie van Gerret Vermeulen naar Oost-Indien, in 't jaar 1668 aangevangen, en in 't jaar 1674 voltrokken. Amsterdam: Jan Claesz, Ten Hoorn.

Wal, S.L. van der, P.J. Drooglever, and M.J.B. Schouten (eds). 1971-1996. Officiële bescheiden betreffende de Nederlands-Indonesische betrekkingen, 19451950. Twenty volumes. The Hague: Rijks Geschiedkundige Publicatiën. [Retrieved from: http:/ / resources.huygens.knaw.nl/retroboeken/nib/\# page $=0$ \&accessor=toc\&view $=$ homePane; accessed on 31-08-2018.]

Watson, C.W. 2006. Of self and injustice; Autobiography and repression in Indonesia. Leiden: KITLV Press.

Wieringa, E.P. 1990. Carita Bangka; Het verhaal van Bangka. Tekstuitgave met introductie en addenda. Leiden: Vakgroep Talen en Culturen van ZuidoostAzië en Oceanië, Rijksuniversiteit Leiden.

Willemsen, Marie-Antoinette. 2015. De lange weg naar Nusa Tenggara; Spanningsvelden in een missiegebied. Hilversum: Verloren.

Wood, James. 2011. "Shelf life; Packing up my father-in-law's library", The New Yorker 7 November 2011. [Retrieved from: https:/ / www.newyorker. com/magazine/2011/11/07/shelf-life; accessed on 23-08-2018.] 